\title{
A taxonomic and distributional survey of marine benthonic Ostracoda off Kerguelen and Heard Islands, South Indian Ocean
}

\author{
MICHAEL A. AYRESS ${ }^{1}$, PATRICK DE DECKKER ${ }^{2} \&$ GRAHAM P. COLES ${ }^{3}$ \\ ${ }^{1}$ Ichron Limited, 5 Dalby Court, Gadbrook Business Centre, Northwich, Cheshire CW9 7TN, UK (e-mail: info@ichron.com). \\ ${ }^{2}$ Department of Geology, The Australian National University, Canberra, ACT 0200, Australia (e-mail: patrick.dedeckker@anu.edu.au). \\ ${ }^{3} 7$ Simpsons Way, Broughton, Chester CH4 0RA, UK (e-mail: GPColes@krithe1.freeserve.co.uk).
}

\begin{abstract}
From an examination of 34 grab and dredge samples ranging from $110 \mathrm{~m}$ to $3584 \mathrm{~m}$ water depth, collected during Eltanin cruise 47 across the Kerguelen Plateau, 26 shallow-water and 35 deep-sea benthonic ostracod species have been identified. Systematic notes and illustrations of the common and some of the rare species are presented. Two new species are described: Philoneptunus cassidyi $\mathrm{n}$. sp. and Taracythere abyssora n. sp. Comparisons made with the Atlantic and SW Pacific Oceans and circumAntarctic regions indicate that the fauna comprises dominantly cosmopolitan deep-sea species while most of the other species have close affinities with the SW Pacific. In the Kerguelen material, seven distinct depth assemblages appear to correspond well with differing watermasses and there is evidence that the relatively shallow position of Antarctic Intermediate Water permits elevation of the upper depth limits of some deep-sea species. Some species have developed ornament of fine reticulation, features not previously seen in those species outside the Kerguelen region. J. Micropalaeontol. 23(1): 15-38, May 2004.
\end{abstract}

\section{INTRODUCTION}

The present study documents benthonic ostracod crustaceans obtained from surface sediment samples on the Kerguelen Plateau and adjacent abyssal regions of the south Indian Ocean, a locality that, with respect to the Ostracoda, has remained largely unstudied since the Challenger Cruise report of Brady (1880). The Kerguelen Plateau is a large topographic high situated in the south-central Indian Ocean, north of Antarctica. The NW-SE trending northern sector of the Plateau extends from approximately $46^{\circ} \mathrm{S}$ north of Kerguelen Island to approximately $56^{\circ} \mathrm{S}$ south of the much smaller Heard Island (Fig. 1). The heavily glaciated Kerguelen Island is $160 \mathrm{~km}$ in length and $5820 \mathrm{~km}^{2}$ in area, with peaks of up to $1965 \mathrm{~m}$, and lies on an aseismic ridge constructed by volcanism from hotspot activity on the Ninetyeast Ridge. Recent investigations as part of the Ocean Drilling Program during ODP leg 183 (Coffin et al., 2000) further confirmed the geological history of this plateau, which indicates it as an uplifted remnant of a Cretaceous ocean plateau that existed to the west of Australia following the separation of India from Western Australia and Antarctica.

The Plateau is an important locality for investigating deep-sea ostracod distribution because of its high latitude and also because conditions that are characteristic of the deep sea, such as low temperatures and high nutrient levels, occur near the surface around Kerguelen. In addition, several watermasses are encountered at the various depths from which the collection originates, thus allowing one to distinguish the relationship of ostracods to depth and watermass characteristics. Deep-sea ostracods from the Southern Ocean are incompletely known because of a lack of sampling and study. Furthermore, previous sampling has indicated generally low ostracod abundance and poor preservation. This study is the first to report species from a wide depth range of material, often well preserved, in the Southern Ocean. Changes seen in the ostracod assemblages with depth, between $110 \mathrm{~m}$ and $3584 \mathrm{~m}$, and their relationship to environmental parameters are the focus of this contribution.
The bathymetric distribution of selected ostracod species from the Kerguelen Plateau found in the present material was reported previously (Ayress et al., 1997). That paper indicated that there may be a correlation of the ostracod distributions

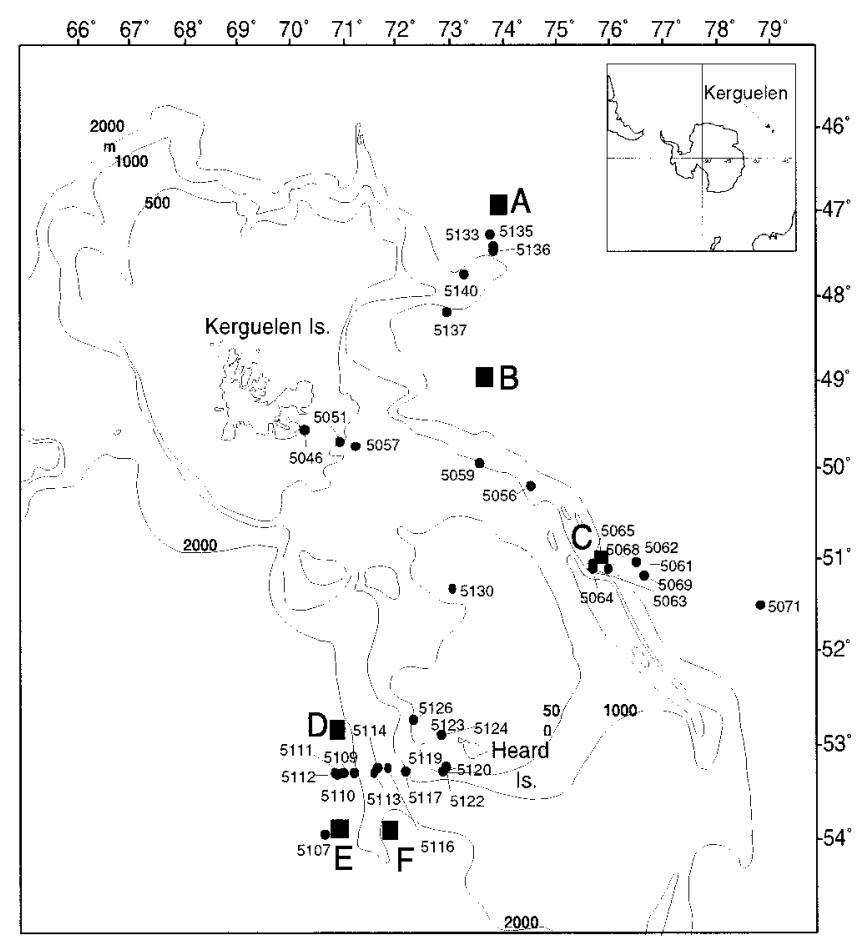

Fig. 1. Bathymetric map of Kerguelen Plateau showing position of samples utilized in this study (filled circles) and the location of hydrographic profiles (filled squares labelled stations A-F) taken from the World Ocean Atlas (1994) datasets and plotted in Figs 2 and 3. Note the $500 \mathrm{~m}, 1000 \mathrm{~m}$ and $2000 \mathrm{~m}$ bathymetric contours which show the extent of the Kerguelen Plateau and also that the southern stations are separated by the Plateau from the other stations. Inset shows position of Kerguelen Island in the Southern Ocean. 
with watermass parameters. The present study analyses the entire fauna found in the available dataset on the Plateau to examine more comprehensively the nature of the ostracod faunal changes and controlling environmental factors across the Plateau.

\section{PREVIOUS RESEARCH ON DEEP-SEA OSTRACODA}

The earliest report on the ostracods from the area of the Kerguelen Plateau was that of Brady (1880), who listed 32 podocopid species from three Challenger stations (149-151). These comprised shallow- and deep-water species most of which were re-illustrated by Puri \& Hulings (1976). Benson (1964) described the results of early research on Antarctic and Southern Ocean ostracods. A comprehensive review of the ostracod faunas of both the high and low Antarctic regions is given in Neale (1967), who also compared cold water shallow Antarctic Ostracoda (e.g. Müller, 1908) with abyssal faunas recorded from the Challenger expedition by Brady (1880), East of Tasmania (Chapman, 1919) and the single abyssal station of Benson (1964). Subsequent research on Recent deep-water ostracod faunas of the circum-Antarctic region includes those of Whatley et al. $(1996,1997)$ on the southern Strait of Magellan and Whatley et al. (1998) from deep waters (900-3925 m) of the Scotia Sea in the western Antarctic. In a series of papers published between 1986 and 1994, Hartmann described the Recent benthonic ostracods of the Antarctic, principally from the waters around the Antarctic Peninsula, including Elephant Island, King George Island and the South Orkney Islands (Whatley et al. (1998) provides a full listing). More recently, Dingle (2002) recorded Ostracoda from $32 \mathrm{~m}$ to $474 \mathrm{~m}$ off Marion Island and indicates Kerguelen affinites. Also of relevance is the work of Briggs (1978) on the Late Pleistocene ostracod fauna of the Taylor Formation from Ross Island in western Antarctica.

Investigations of ostracod species distribution and their relationship to watermasses have increased over the last decade mainly motivated by an interest in reconstructing past ocean temperatures for prediction of possible future changes in global climate (Dingle et al. 1989, 1990; Dingle \& Lord, 1990, Corrège 1993, Cronin et al., 1994, 1995). These studies suggest that the distribution of ostracod assemblages in the ocean is influenced to a large degree by watermass structure. Vertical changes in species composition and dominance appear to coincide with levels where watermass characteristics (e.g. temperature, salinity, nutrients, dissolved oxygen) are gradational. Detailed regional ecological studies in the Atlantic indicate that on the shelf and upper slope, species distribution is controlled by both water physico-chemical and substrate characteristics, whereas for bathyal and abyssal species salinity and temperature are primary controlling factors (Benson et al., 1983; Dingle \& Giraudeau, 1993; Dingle, 1994). Dingle \& Lord (1990) identified five faunal sequences based on key ostracod taxa and discussed their distribution relative to deep watermasses in the Atlantic Ocean, while Ayress et al. (1997) review the relationship of comparable benthonic ostracod taxa with deep watermasses in the Southwest Pacific, Southern and Atlantic Oceans, including selected taxa from the present study area/dataset on the Kerguelen Plateau. They found that while no taxa were confined to individual watermasses, species upper depth limits were controlled to a large degree by watermass structure.

\section{MATERIAL AND METHODS}

This study is based on prepared ostracod assemblage slides made available by Richard Benson (National Museum of Natural History, Washington, DC). The original material was obtained using 34 grab and dredge samples collected during Eltanin cruise 47 to the Kerguelen Plateau in 1971. (An additional sample from Eltanin cruise 43 , located at $52^{\circ} 38^{\prime} \mathrm{S}$, $75^{\circ} 25^{\prime} \mathrm{W}, 787 \mathrm{~m}$, is also used for illustrative purposes only.) The samples range from $110 \mathrm{~m}$ to $3584 \mathrm{~m}$ water depth along two transects east of Kerguelen and southwest of Heard Island, as shown in Figure 1 and Table 1.

The sediment samples from shallower-water (110-457 m) stations were predominantly sands with minor gravels. Samples recovered at $600 \mathrm{~m}$ down to $3584 \mathrm{~m}$ are dominated by globigerinid and diatom oozes; locally present sands and coarsergrained sediments are more than likely of glacio-marine provenance. A narrow water temperature total range of $0.11-$ $2.6^{\circ} \mathrm{C}$ is recorded from the combined sample stations; salinities range from $33.916 \mathrm{psu}$ at $110 \mathrm{~m}$ to $34.581-34.767 \mathrm{psu}$ between $600 \mathrm{~m}$ and $3584 \mathrm{~m}$; water density increases from 27.08 at $110 \mathrm{~m}$ to 27.87 at $3584 \mathrm{~m}$ (Fig. 2, see also Fig. 3). Use is also made of the physicochemical measurements given in the World Ocean Atlas (1994) for stations in the area of interest (see Fig. 1, filled squares labelled stations A-F, and tabulated in Table 2).

Samples were originally washed through a $150 \mu \mathrm{m}$ sieve; hence the recorded fauna is limited to medium- or large-sized species and would be lacking juvenile specimens if originally preserved. No record of the original sample size has been found. All ostracods extracted from the retained sediment were placed on faunal slides. None were stained or preserved in alcohol. The specimens are mainly disarticulated valves, empty carapaces with less than $1 \%$ of the carapaces retaining desiccated soft-parts (Table 3). All specimens have been identified to species level for this report. Generally, only those species found commonly (in more than one sample) at slope to abyssal depths (i.e. at and below $600 \mathrm{~m}$, where samples lacked presumed allochthonous shallow-marine, sighted ostracods) are included in the taxonomic review, although some rare species are also included for illustration or comment.

Full details of the ostracod occurrences in all the analysed samples between $110 \mathrm{~m}$ and $3584 \mathrm{~m}$ are presented in Figure 4, which also gives the total number of specimens recorded at each depth level. All type and illustrated specimens are deposited in the National Museum of Natural History, Washington, D.C. and are catalogued with numbers prefixed USNM. In the following discussion, the water depth terminology follows that employed by Van Morkhoven et al. (1986) in their study of Cenozoic cosmopolitan deep-water benthonic foraminifera.

\section{RESULTS}

\section{Oceanographic characteristics of waters of the Kerguelen Plateau}

Much debate has prevailed about the position of the Kerguelen Plateau with respect to its position with Southern Ocean boundaries. This was recently reviewed by Orsi et al. (1995) and Belkin 


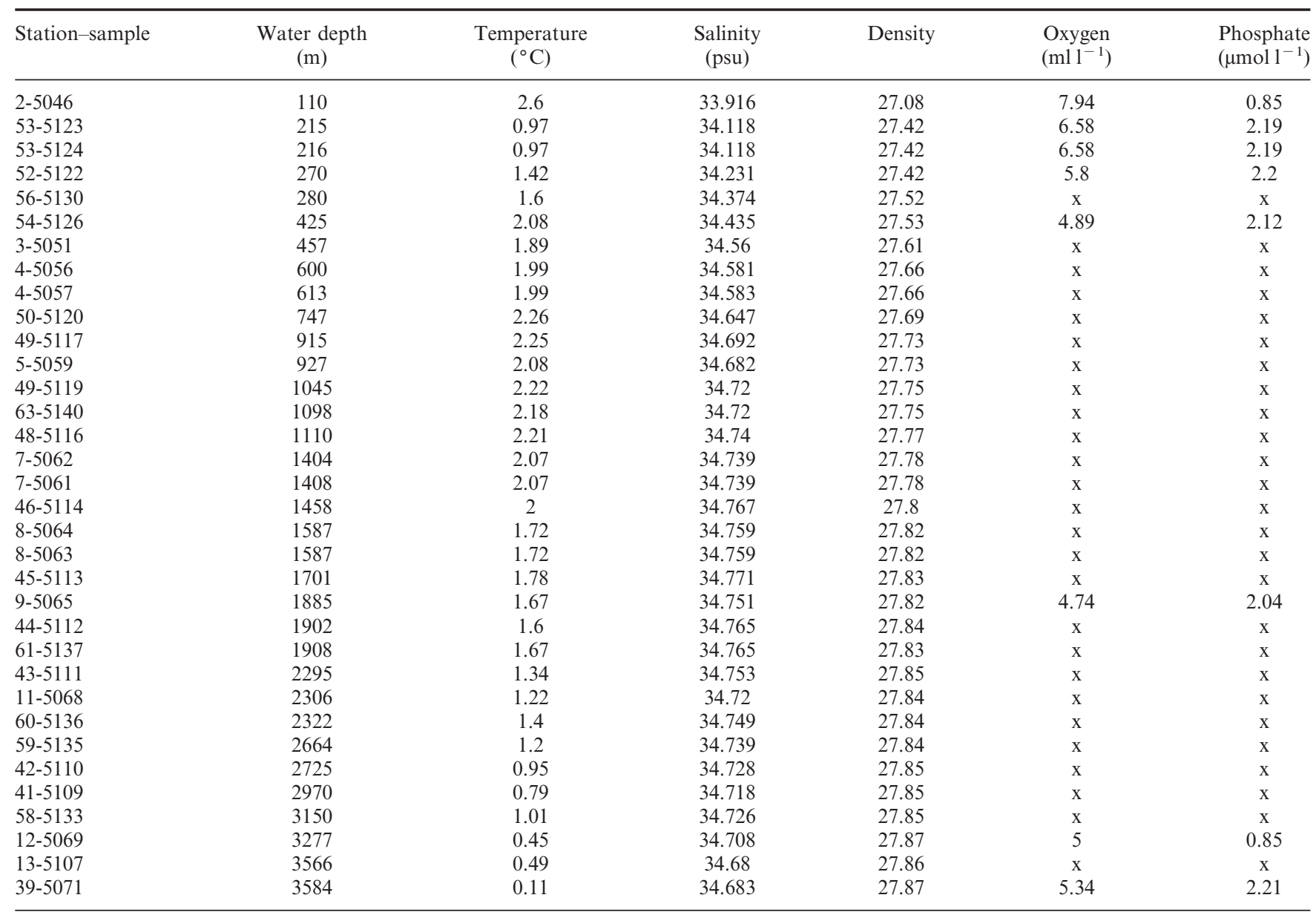

Table 1. List of samples utilized in this study with hydrographic data collected at those sites during Eltanin Cruise 47.

\& Gordon (1996) who concurred that the northern portion of the Polar Front is located near Kerguelen. Nevertheless, surface waters around Kerguelen Island display much seasonal variation in salinity, temperature and nutrient levels (Fig. 3). The Plateau itself is also located within the region of iceberg drifts, and erosion due to glacial activity on the island must contribute to the coarse sediment (sands and gravels) that is deposited on the sea floor down to $500 \mathrm{~m}$. In addition, turbidity flows are a likely feature of this tectonically active portion of an ancient continental crust that has witnessed much volcanic activity. Ostracod shells displaced downslope are usually readily recognized as such by their preservation, morphology (e.g. presence of eyespot) or unusual depth of occurrence (Passlow, 1997).

The waters surrounding Kerguelen Island only represent a small fraction of the vast Kerguelen Plateau that is immersed by Southern Ocean waters. It is of no surprise, therefore, to find that the water characteristics down to $2000 \mathrm{~m}$ in the northern end of the Plateau (e.g. $74^{\circ} \mathrm{E} 47^{\circ} \mathrm{S}$, called here Station A) differ greatly from those waters east or south of the Plateau (e.g. $76^{\circ} \mathrm{E} 51^{\circ} \mathrm{S}$, called here Station $\mathrm{C}$, and those near $70^{\circ} \mathrm{E}$ and $53-54^{\circ} \mathrm{S}$, herewith labelled Stations D-F) as shown in the physicochemical profiles illustrated in Figure 2.

Several local watermasses are recognized, see Table 2 and Figures 2-3, and will not be described as they belong to well-known watermasses characteristic of the Southern Ocean (Tomczak \& Godfrey, 1994).

\section{Bathymetric distribution of the Ostracoda}

It may be seen from Figure 4 that the ostracod fauna recorded from the Kerguelen Plateau includes shallow-marine to deep-sea taxa, together with a few (e.g. Bradleya normani) showing a wide bathymetric distribution. As indicated by peaks in species' upper and lower depth limits and, to some extent, peaks in diversity (see Fig. 5), a depth of around $500 \mathrm{~m}$ marks a distinct change in the nature of the ostracod fauna. As in other basins of the world's oceans, a dramatic increase in the deep-sea dominant Krithe (Fig. 6) is seen from around $500 \mathrm{~m}$. With increasing depth beyond $500 \mathrm{~m}$ the upper limits of various deep-sea (psychrospheric) species are gradually encountered. A dendrogram of similarity analyses (see Fig. 7) based on species' presence/ absence data presented in Figure 4, indicates clearly five depth assemblages (labelled 1-5), with the lower two further divisible into four distinct assemblages. Comparing the distribution of these assemblages against watermass (Figs 4, 8), one can suggest that the depth ranges of ostracod species are governed to a high degree by differing hydrographic properties of the various watermasses. The observed ostracod assemblage composition 

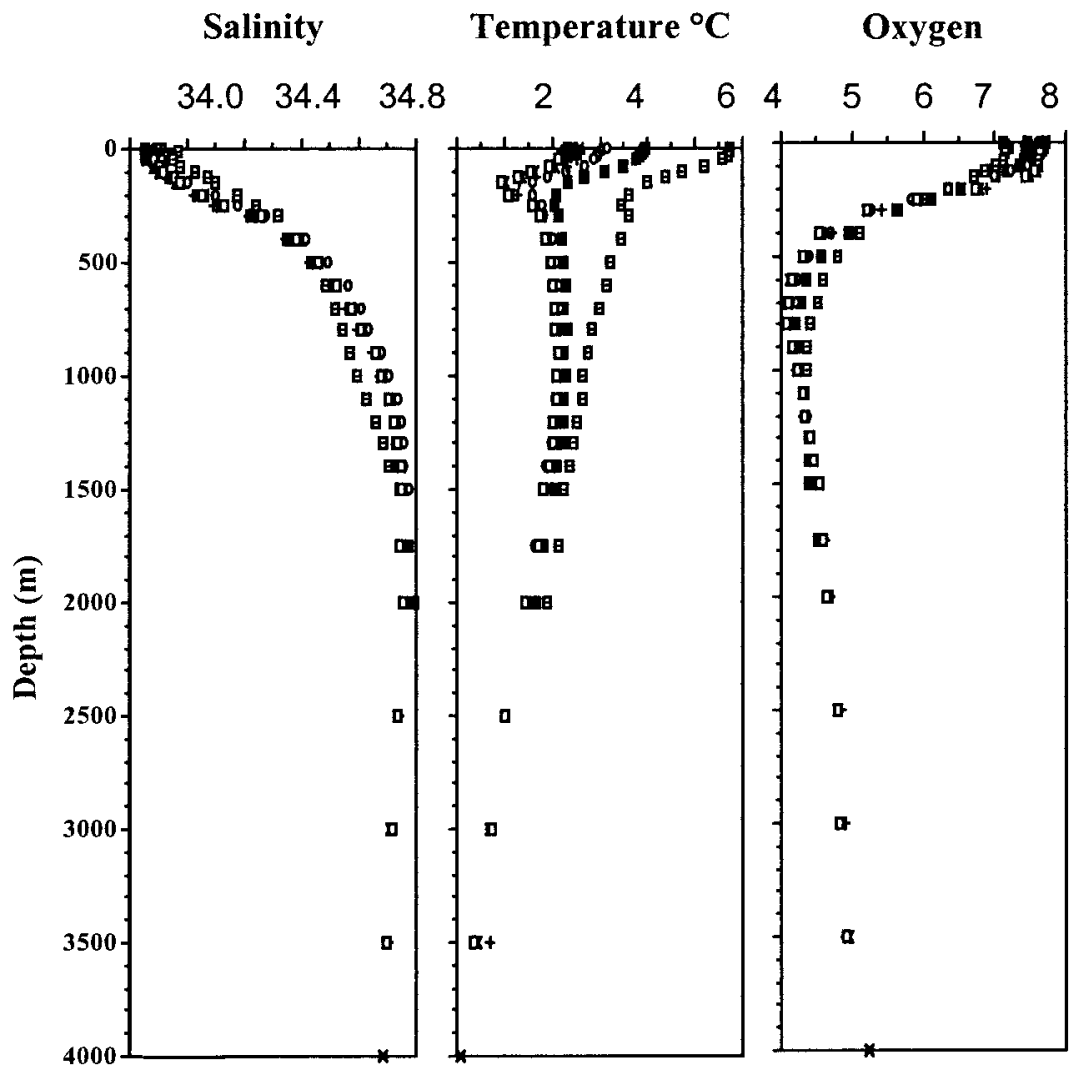

Phosphate

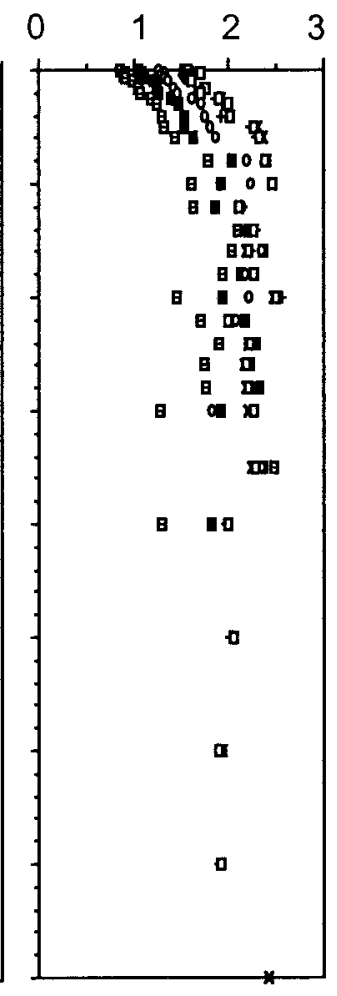

Nitrate

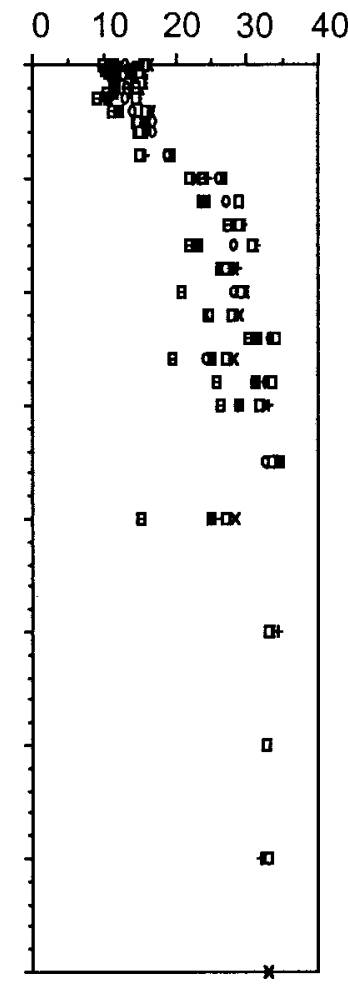

Fig. 2. Mean annual physicochemical parameters obtained from the World Ocean Atlas (1994) for all the stations identified in Figure 1. Different symbols refer to the different stations (A-F) displayed in Figure 1, as follows: square with dot inside, Station A; filled square, Station B; open circle, Station C; straight cross, Station D; oblique cross, Station E; open square, Station F. Values per litre for dissolved oxygen are in $\mathrm{ml} 1^{-1}$, phosphate in $\mu \mathrm{mol} 1^{-1}$ and nitrate in $\mu \mathrm{mol} 1^{-1}$.

occurring within each watermass appears to be significantly distinct.

In the Subantarctic Upper Water (SAUW), the ostracod fauna is mainly composed of typical shallow-marine circumAntarctic species, notably the hemicytherids Patagonacythere wyvillethomsoni and Hemicythere kerguelenensis, together with Neonesidea labiata and Xestoleberis setigera. The shallowestmarine sample analysed at $110 \mathrm{~m}$ within Upper SAUW, contains the dominant species Patagonacythere wyvillethomsoni and Loxoreticulatum fallax, an assemblage (Cluster assemblage 1) significantly different from deeper samples $(215-280 \mathrm{~m})$ taken from within Lower SAUW that consists of the Cluster 2 assemblage, characterized most notably by the addition of species Bradleya normani and Henryhowella sp.

In the samples of upper bathyal depth (280-457 m) a transition from a characteristically shallow to deep-sea fauna is seen. This faunal change is possibly the most pronounced of the entire ostracod depth zonation recorded here, and clearly influenced by the position of the Antarctic Intermediate Water (AAIW). The AAIW core, at around $500 \mathrm{~m}$, appears to be a significant factor controlling both the upper depth limit of Assemblage 3 species (e.g. Krithe cf. capensis and Philoneptunus cassidyi), as well as the lower depth limits of almost all species occurring in SAUW. Dingle et al. (1990) also found the AAIW core, a salinity minimum zone, to be a significant factor in controlling faunal depth distribution. For additional details on watermasses in the Indian Ocean sector of the austral oceans, refer to the recent work of Müller \& De Deckker (2003) which shows that the AAIW is definitely a low salinity watermass characteristic of low temperatures $\left(2-4^{\circ} \mathrm{C}\right)$. Here, around Kerguelen Plateau, it is somewhat shallower and that explains the 'shallower' depth distribution for some ostracod species. Rare specimens of the characteristic deep-sea species Legitimocythere acanthoderma are also noted close to the upper boundary of AAIW at and below $425 \mathrm{~m}$. Compared to elsewhere in the world's oceans, the relatively shallow position of AAIW over the Kerguelen Plateau has allowed some species, particularly $L$. acanthoderma and $P$. cassidyi, to reach unusually shallow limits.

In the deep-water globigerinid and diatom oozes sampled at and below $600 \mathrm{~m}$ within the AAIW and Circumpolar Deep Water (CDW) deep-water species dominate the assemblages. Relatively rare, allochthonous shallow-marine taxa identified by eye tubercles (e.g. Cativella bensoni) are locally present down to $1587 \mathrm{~m}$, but are extremely rare below this depth. Eye tubercles in Bradleya normani are reduced in size down to $613 \mathrm{~m}$ and absent at, and below, $747 \mathrm{~m}$.

The upper depth limits (UDL) of four species (Krithe reversa, Trachyleberis bathymarina, Henryhowella cf. dasyderma and Poseidonamicus aff. ocularis) coincide with the upper boundary of the CDW watermass and characterize Assemblage Cluster 4a of CDW Upper watermass. From 1200 m, where temperatures are less than $2{ }^{\circ} \mathrm{C}$, Lower CDW (I) Assemblage Cluster $4 \mathrm{~b}$ 


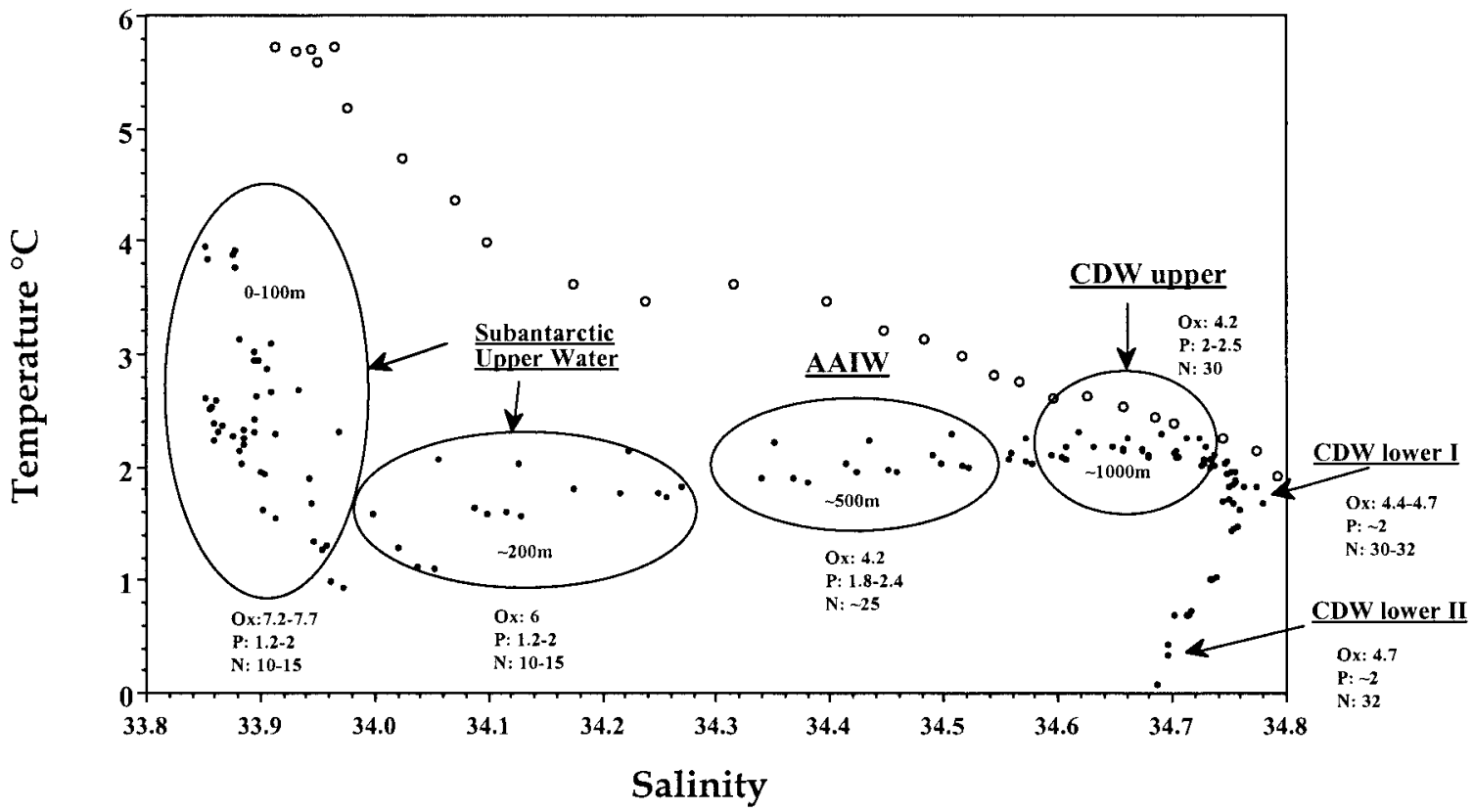

Fig. 3. Annual salinity-temperature measurements for the Kerguelen Plateau, obtained from the World Ocean Atlas (1994) for the stations in Figure 1. The water samples are grouped in respective watermasses and their additional characteristics are given (OX, dissolved oxygen; P, phosphate; N, nitrate) and are also given in Table 1 . Note that the northernmost station $\left(74^{\circ} \mathrm{E}, 47^{\circ} \mathrm{S}\right.$ ) (open circles) has different characteristics from the other stations (dots). AAIW, Antarctic Intermediate Water; CDW, Circumpolar Deep Water.

species are seen, notably Krithe cf. dolichodeira and Pelecocythere trinidadensis. Further decrease in temperature with depth appears to be an important factor for Cluster Assemblage 5 , comprising additional 'psychrospheric' species within watermass CDW Lower (II). The assemblage is similar to that of CDW Lower (I) but consists of additional species from $1902 \mathrm{~m}$ (e.g. Bathycythere audax and Poseidonamicus major). The cluster analysis separates a further grouping in the deepest samples from $3277 \mathrm{~m}$ to $3584 \mathrm{~m}$. This is mainly because several species have their lower depth limits in the sample above, at $3150 \mathrm{~m}$, but also additional species occur at and below $3150 \mathrm{~m}$ (e.g. Pterygocythere mucronalata and Taracythere abyssora) and below $3584 \mathrm{~m}$ (Dutoitella suhmi and Vitjasiella belyaevi), where they inhabit the coldest temperatures $<1^{\circ} \mathrm{C}$, recorded in this study.

Faunal comparison and affinities

A total of 35 deep-sea species (those occurring >500 m) recovered from the Kerguelen Plateau are listed in Table 3, of which, five (Bythocythere sp., Henryhowella sp., Macropyxis sp.,
Parakrithe sp. and Polycope sp.) are recorded in open nomenclature. The remaining 29 species are listed in Table 4, together with their recorded Quaternary and Recent occurrences in five selected deep-water study areas (in which one can be confident that species taxonomy does not vary significantly from that of the present study) in order to show the geographical affinities of the Kerguelen deep-water ostracod fauna. The areas comprise the North Atlantic Ocean (as defined by Whatley \& Coles, 1991), the Southeast Atlantic off southwest Africa studied by Dingle et al. (1990), the Southwest Atlantic area including the Strait of Magellan and Scotia Sea (Whatley et al., 1996, 1997, 1998) and the Northeastern Indian and Southwest Pacific Oceans (Whatley \& Ayress, 1988; Coles et al., 1990). Additional data on the distribution of Krithe species are taken from Coles et al. (1994) and Ayress et al. (1999).

From Table 4 it can be seen that the majority of deep-water species recorded on the Kerguelen Plateau also occur in one or more of the other deep-sea areas, with 14 taxa previously known from three or more of the regions. This is not unexpected since the Southern Ocean is in direct communication with all the other

\begin{tabular}{|c|c|c|c|c|c|c|c|}
\hline Name of watermass & Additional subdivisions & $\begin{array}{l}\text { Depth } \\
\text { (m) }\end{array}$ & $\begin{array}{l}\text { Salinity } \\
\text { (psu) }\end{array}$ & $\begin{array}{l}\text { Temp. } \\
\left({ }^{\circ} \mathrm{C}\right)\end{array}$ & $\begin{array}{c}\text { Dissolved } \\
\text { oxygen }\left(\mathrm{ml} \mathrm{1}^{-1}\right)\end{array}$ & 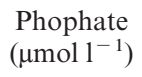 & $\begin{array}{c}\text { Nitrate } \\
\left(\mu \mathrm{mol} \mathrm{1} 1^{-1}\right)\end{array}$ \\
\hline Subantarctic Upper Waters & Upper & $0-100$ [100] & $33.82-32.95[33.85]$ & $2-4$ & $7.2-7.7$ & $1.2-2$ & $10-15$ \\
\hline Antarctic Intermediate Water & & $300-500$ & $34.3-34.5$ & c. 2 & 4.2 & $1.8-2.4$ & 25 \\
\hline \multirow[t]{3}{*}{ Circumpolar Deep Water } & Upper & $500-1000$ & $34.6-34.7[34.7]$ & 2 & c. 4.2 & $2.2-2.5$ & 30 \\
\hline & Lower I & $1000-c .1500$ & c. 34.75 & $<2$ & $4.4-4.7$ & $\sim 2$ & $30-32$ \\
\hline & Lower II & c. $1500-3500$ & c. 34.7 & $<1$ & 4.7 & c. 2 & 32 \\
\hline
\end{tabular}

Values in brackets are the mean depth representing each watermass.

Table 2. Characteristics of the different watermasses encountered in the Kerguelen Plateau region taken from a variety of sources. 


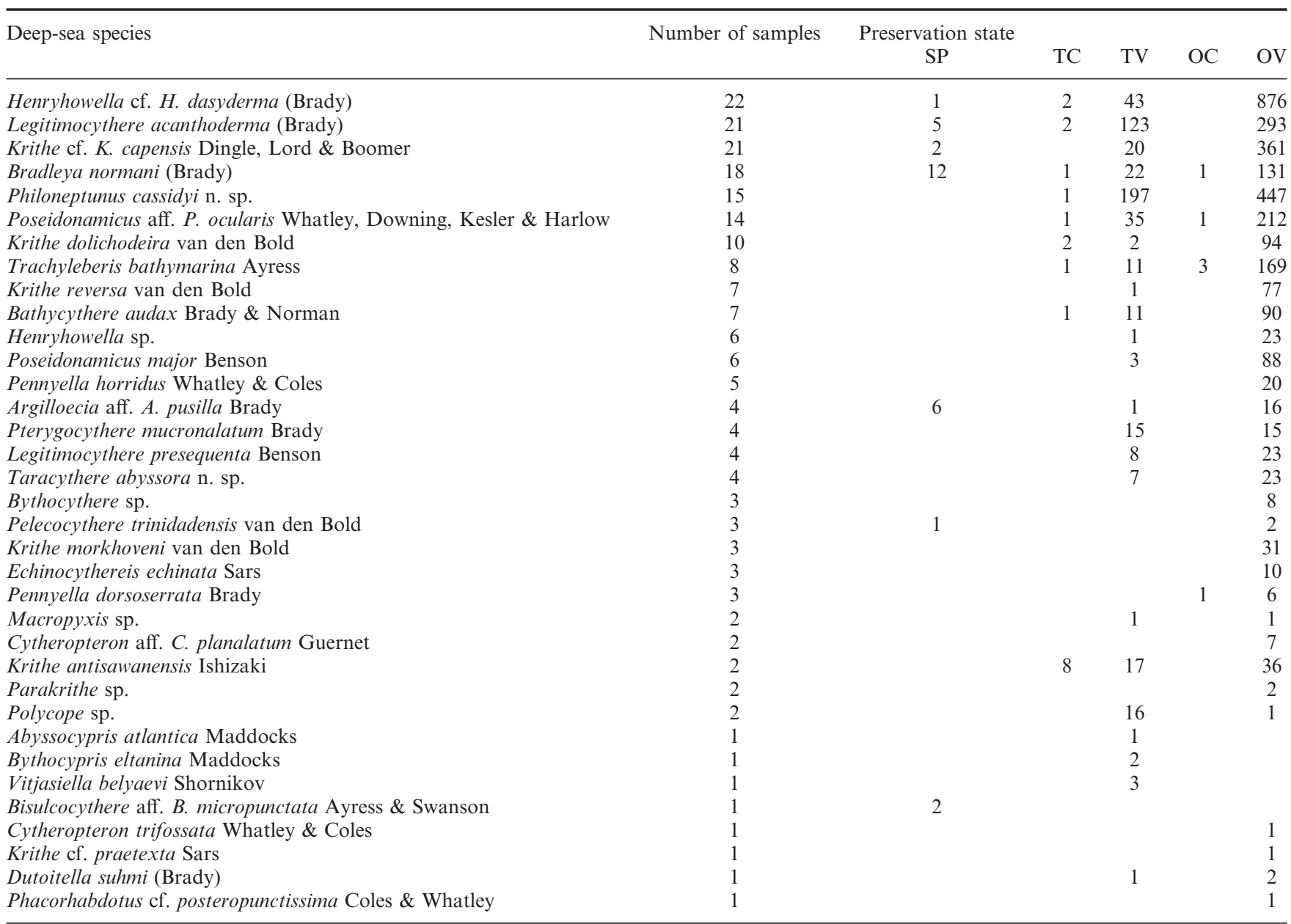

SP, soft-parts present; TC, transparent carapace; TV, transparent valve; OC, opaque carapace; OV, opaque valve.

Table 3. Nature of specimen preservation and deep-sea species frequency found in 27 samples, between $500 \mathrm{~m}$ and $3584 \mathrm{~m}$.

major ocean basins. The Circum-polar Current would obviously aid benthonic ostracod dispersal. If so, it could be speculated that strongest affinity of the Kerguelen fauna would be seen with the west Indian Ocean and South Atlantic and least affinity with the Pacific. However, most species are previously documented from the relatively well-studied North Atlantic (19) and Southwest Pacific (20), with fewer (13) from the Indian Ocean and off southwest Africa (9). Fewest (6) species are shared with the Southwest Atlantic, probably due to the lack of research on bathyal and abyssal faunas from this area, despite the occurrence of typically psychrospheric species at shallow shelf depths due to the cold water temperatures and strong upwelling in the southern Strait of Magellan (Whatley et al., 1997). Further research, especially on the relatively poorly known Indian Ocean faunas will undoubtedly reveal more cosmopolitan species, as will further study on small taxa, particularly the Cytheruridae, and on genera such as Krithe where species-level taxonomy has been problematic. Nevertheless, the Kerguelen fauna does contain elements of exclusively Pacific affinity. Philoneptunus, represented by abundant $P$. cassidyi in the present study, is the first record of this genus away from the Australian/New Zealand region (Whatley et al., 1992). Also new are the occurrences of
Bisulcocythere, Clinocythereis and Trachyleberis bathymarina, taxa previously known only from the Australasian region (Ayress \& Swanson, 1991; Ayress, 1993); these taxa are clearly more widely distributed in the Southern Hemisphere than previously reported. Other species of 'eastern' affinity include Cytheropteron aff. C. planalatum and Taracythere abyssora, although these species have not, as yet, been definitely recorded from the Pacific. Few taxa seem to be of Atlantic origin; Buntonia, a genus common in the Atlantic and rare in the western Indian Ocean is absent from the Kerguelen material. Echinocythereis echinata has a similar distribution to Buntonia and is found in this study, albeit very rarely.

\section{Observations on preservation state and unusual carapace calcification}

The physical appearance of the ostracod valves found in this study varies greatly. Pristine valves that are transparent, often with soft-parts intact, were found to predominate at shallow stations down to $457 \mathrm{~m}$. White opaque and corroded valves become increasingly numerous from $600 \mathrm{~m}$ onwards. Two samples, at $1098 \mathrm{~m}$ and $1885 \mathrm{~m}$, are represented only by a few severely corroded specimens, whereas other deep samples 

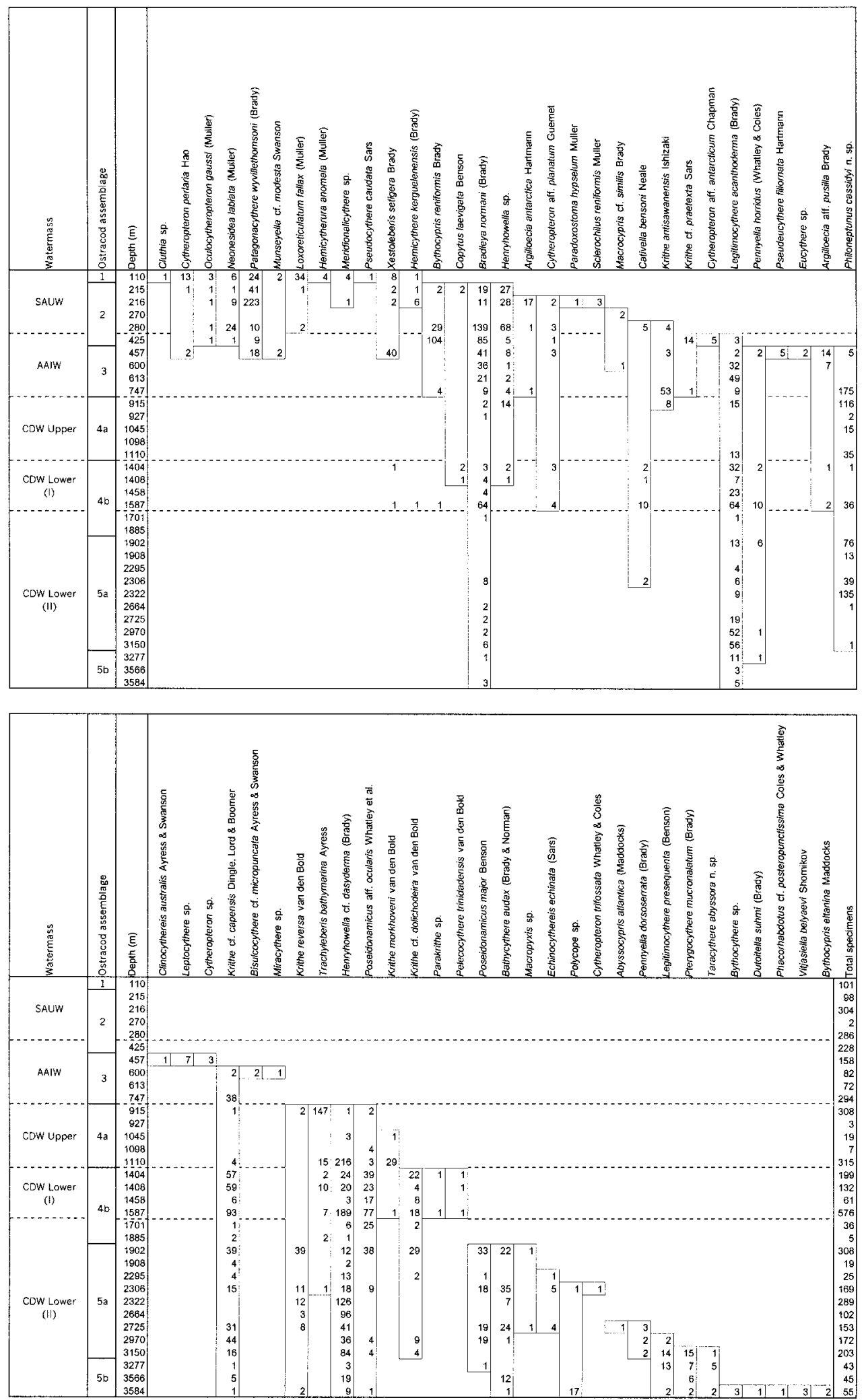

Fig. 4. Species depth distribution and abundance. Vertical borders indicates in situ ranges used for present/absent occurrences employed in the assemblage analyses dendrogram (Fig. 7). Numbers outside borders are considered to be downslope displaced specimens. Dashed lines indicate watermass boundaries. Ostracod assemblages are those indicated in the dendrogram (Fig. 7). AAIW, Antarctic Intermediate Water; CDW, Circumpolar Deep Water; SAUW, Subantarctic Upper Water. 
M. A. Ayress et al.
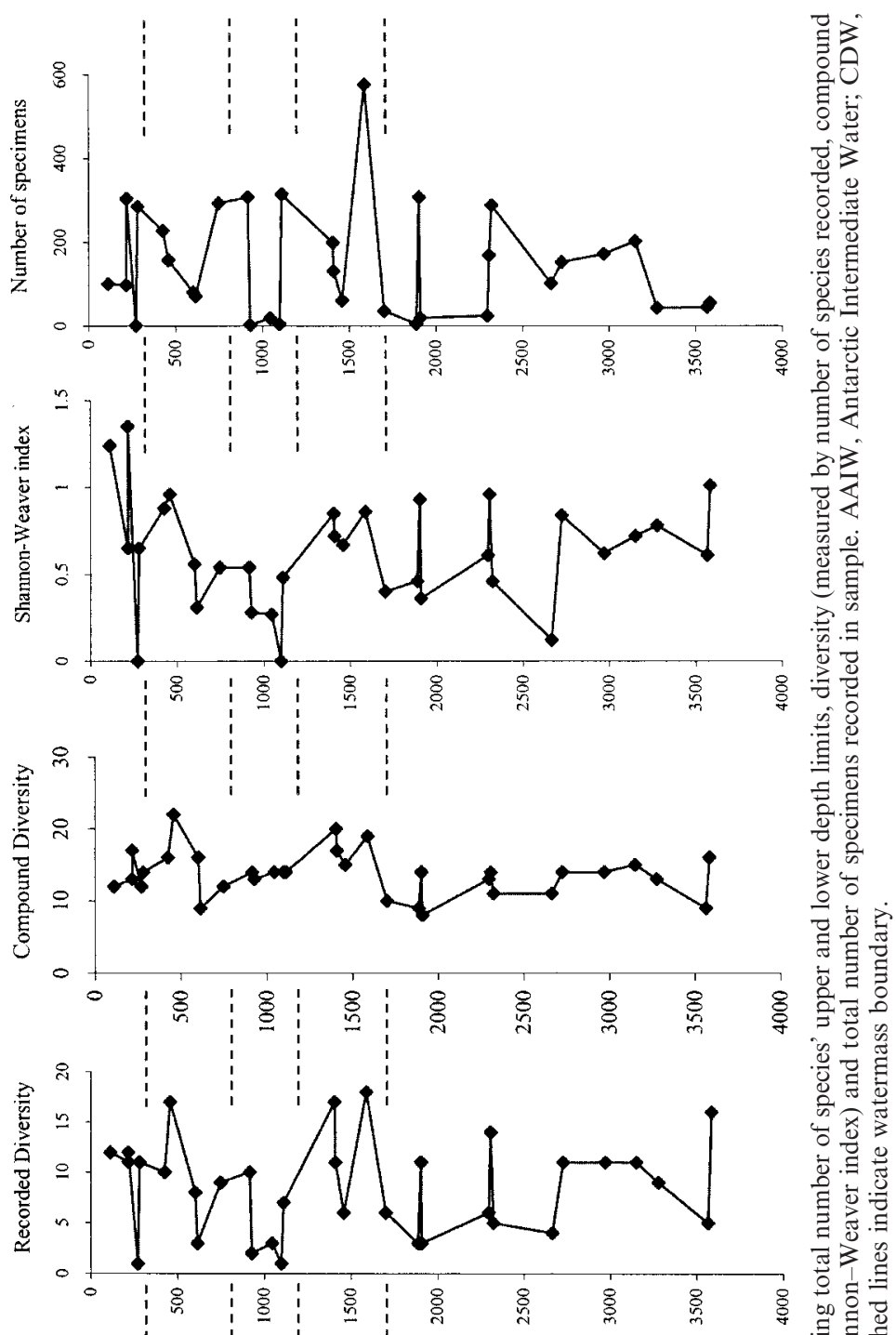

诺
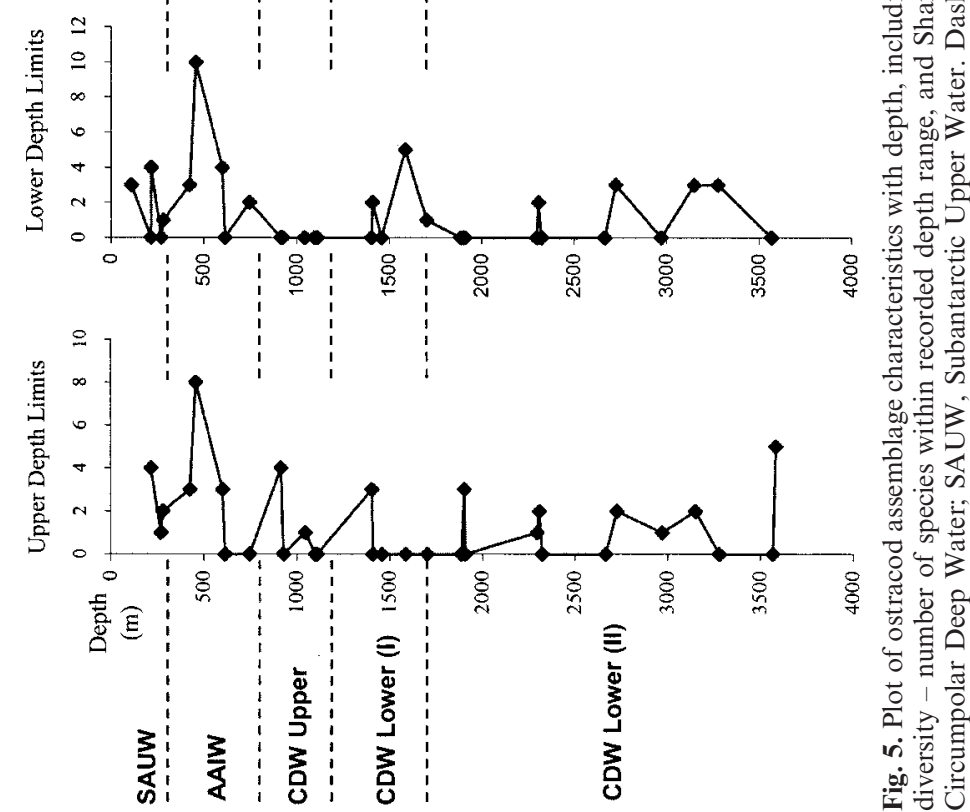


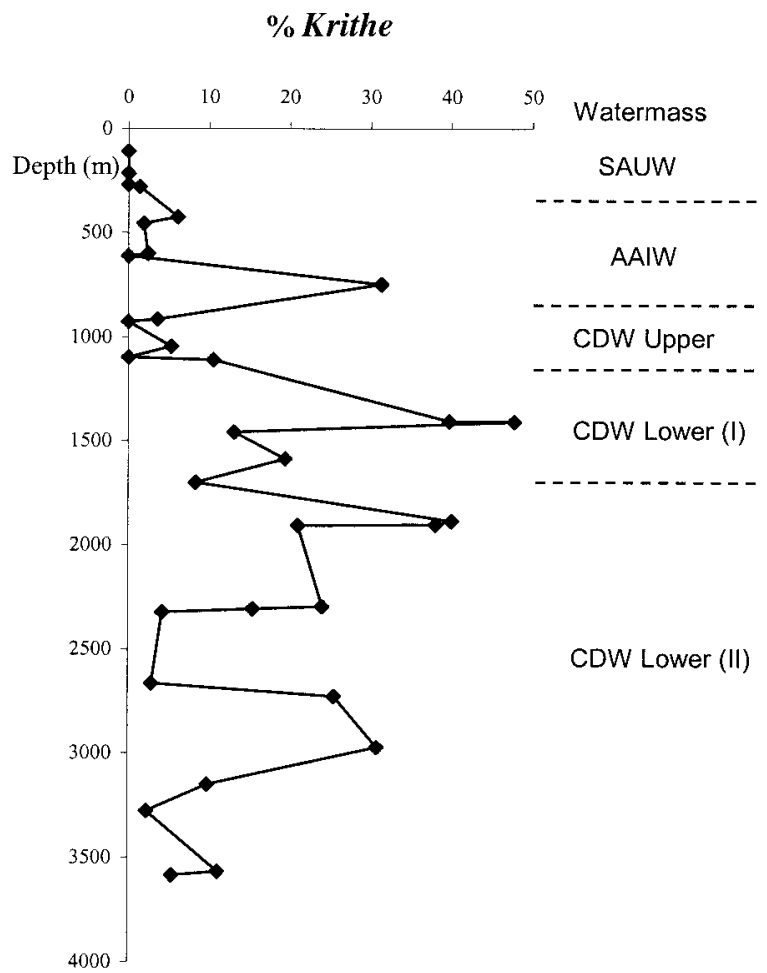

Fig. 6. Plot of percentage Krithe specimens with depth. Watermass boundaries are also indicated. AAIW, Antarctic Intermediate Water; CDW, Circumpolar Deep Water; SAUW, Subantarctic Upper Water.

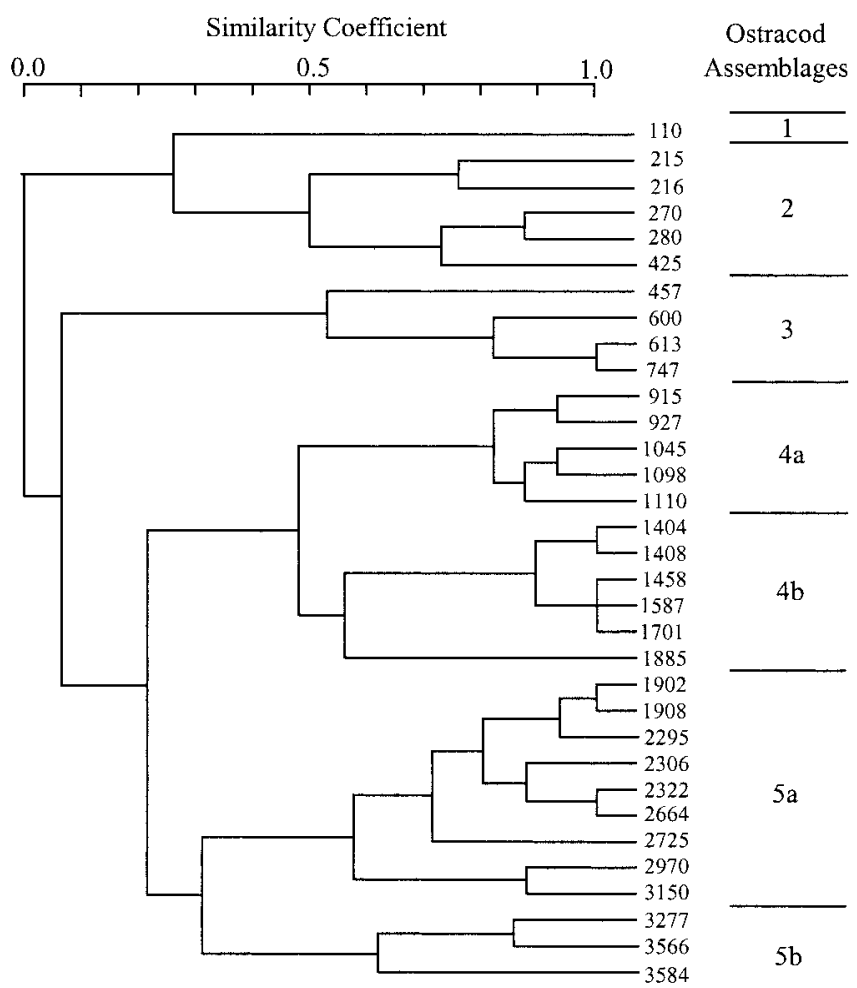

Fig. 7. Ostracod assemblages indicated by similarity analyses dendrogram using species presence/absence data shown in Figure 4. contain abundant specimens showing a range of glassy and opaque states, the latter more frequent with increasing depth. This trend in deteriorating preservation with depth mainly reflects the effects of the lysocline, where seawater progressively approaches carbonate undersaturation and becomes increasingly so with depth. Nevertheless, transparent valves were sometimes found at considerable depth and these, presumably, were sampled live or soon after their death. During life, a thin chitinous covering provides protection from corrosion. After death, the coating decomposes or is attacked by bacteria, thus, exposing the calcitic shell to chemical corrosion. A number of factors, such as rapidity of burial within the sediment (Kaesler et al., 1993) and shell morphology (Swanson, 1995) retard shell corrosion.

Corrosion of calcite within the lysocline is a global phenomenon but certain morphological aspects of the Kerguelen material are apparently unique to the region and, therefore, deserve comment. Fine reticulation occurs on the surface of usually smooth-shelled cosmopolitan species, such as Pterygocythere mucronalata. Similarly, Legitimocythere praesequenta has a fine lace-like reticulum (see Pl. 1, fig. 16) and, perhaps, this phenomenon is best seen in Philoneptunus cassidyi where the secondary reticulum is increasingly apparent with depth. Clearly, microreticulation development has a genetic basis in some species (Neil, 2002), however, observation leads to the conclusion that for the taxa noted above, there appears to be a direct relationship between microreticulation development and calcite content within waters of the lysocline.

\section{CONCLUSIONS}

Over 60 benthonic ostracod species have been found in grab and bottom dredge samples ranging from $110 \mathrm{~m}$ to $3584 \mathrm{~m}$ water depth across the Kerguelen Plateau, a region hitherto lacking study of its Ostracoda for over a century. Two new species are described: Philoneptunus cassidyi n. sp. and Taracythere abyssora $\mathrm{n}$. sp. The ostracod fauna comprises dominantly cosmopolitan deep-sea species, while most of the other species have close affinities with the SW Pacific. In the Kerguelen material, at least seven distinct depth assemblages appear to correspond well with differing watermasses in contact with the seafloor at water depths ranging from $110 \mathrm{~m}$ to $3584 \mathrm{~m}$. The relatively shallow position of the AAIW has allowed some species to extend to an unusually shallow limit. This study confirms previous suggestions that ostracod species could provide useful proxies for various watermasses of the deep sea.

\section{ACKNOWLEDGEMENTS}

This study is dedicated to Richard Benson who died in 2003. He very generously allowed access to the picked slides housed at National Museum of Natural History, Washington, DC upon which the present study is based. The original samples were collected during Eltanin cruise 47. This study developed from a collaboration established during discussions at an international workshop of deep-sea ostracod researchers held in Reston, Virginia in 1993, organized by Tom Cronin and sponsored by the United States Geological Survey. Rosalie Maddocks of the University of Houston is gratefully thanked for her extensive and helpful comments on an early version of the manuscript. Alicia Moguilevsky helped with comparison of unpublished 


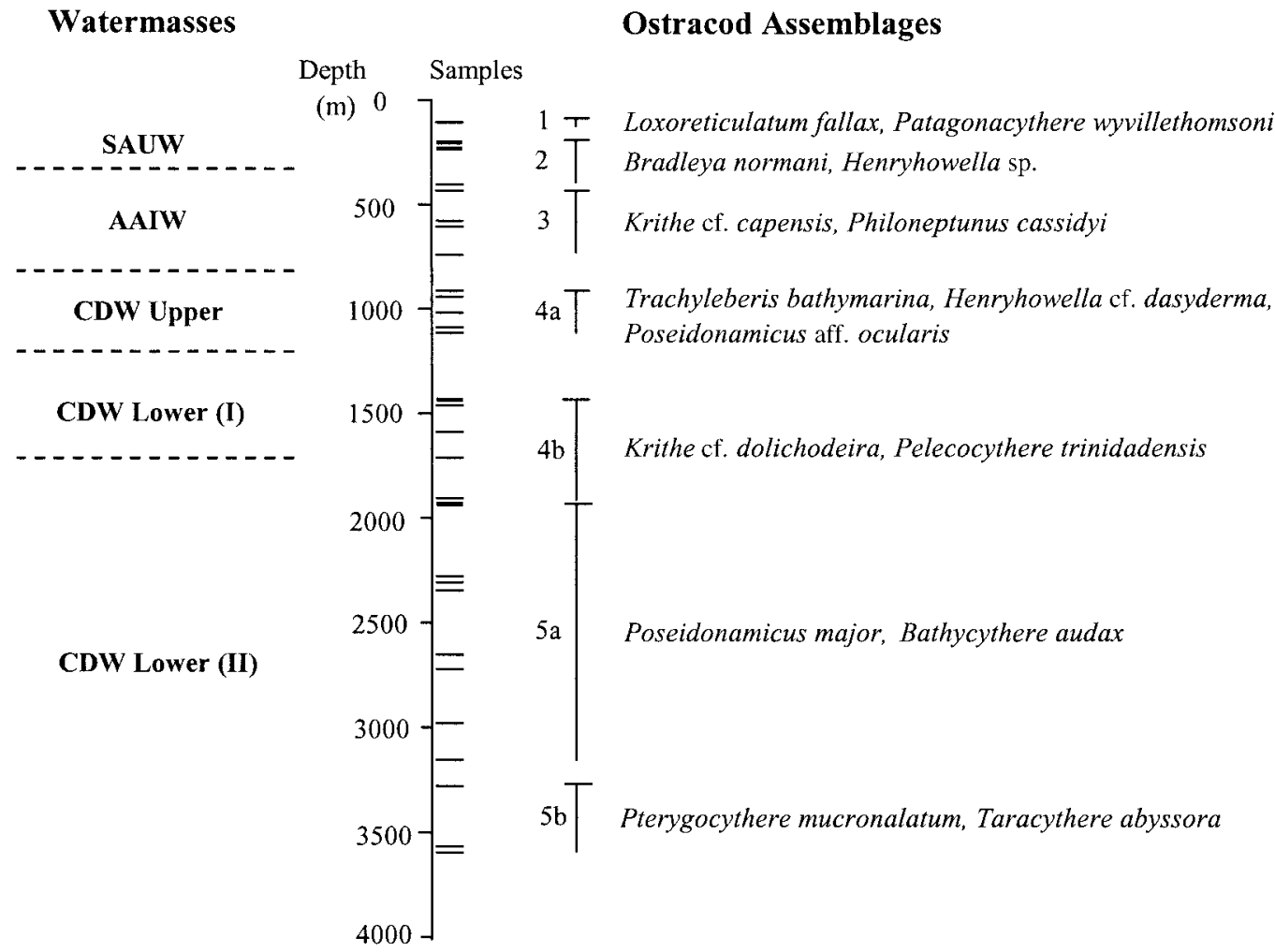

Fig. 8. Summary of ostracod assemblage depth distribution, sample spread and watermasses. Species listed are those that characterize the assemblages, the upper depth limits of these species occur at the top of their respective assemblage range. AAIW, Antarctic Intermediate Water; CDW, Circumpolar Deep Water; SAUW, Subantarctic Upper Water.

thesis material held at University College of Wales, Aberystwyth. Inconsistencies in original records of the Eltanin sample data were corrected by the efficient service of Steve Hoven, then curator of the Antarctic Research Facility, Florida State University. Support by the Smithsonian Institution in the Eltanin voyages is also acknowledged. The Panmap program of Pangaea (www.pangaea.de) was used to plot the maps used in Figures 1 and 2.

\section{APPENDIX}

\section{SYSTEMIC DESCRIPTIONS}

Class Ostracoda Latreille, 1806

Order Podocopida Müller, 1894

Suborder Podocopina Sars, 1866

Superfamily Cytheracea Baird, 1850

Family Trachyleberididae Sylvester-Bradley, 1948

Genus Philoneptunus Whatley, Millson \& Ayress, 1992

\section{Philoneptunus cassidyi $\mathrm{n}$. sp.}

(Pl. 2, figs 1-11)

1992 Philoneptunus sp. 3 Whatley, Millson \& Ayress: 55, pl. 3, figs 16,18 .

Derivation of name. After Dennis Cassidy, former curator of the Antarctic Research Facility at Tallahassee where most of the Eltanin collections are held, and who helped us enthusiastically with the supply of core samples, publications and unpublished reports over many years.
Diagnosis. A blind, secondarily reticulate species of Philoneptunus with a continuous anterior and ventro-lateral ridge, strong postero-dorsal 'L'-shaped ridge and short posteromedian ridge.

Material. 650 adult and juvenile specimens.

Type material and dimensions. Weakly secondarily reticulate form: female left valve (USNM 483934), length $1.25 \mathrm{~mm}$, height $0.83 \mathrm{~mm}$; male left valve (USNM 483935), length $1.33 \mathrm{~mm}$, height $0.80 \mathrm{~mm}$; male right valve (USNM 483936), length $1.32 \mathrm{~mm}$, height $0.73 \mathrm{~mm}$. Female length range: $1.22-1.32 \mathrm{~mm}$, average $1.26 \mathrm{~mm}$; male length range: $1.28-1.38 \mathrm{~mm}$, average $1.33 \mathrm{~mm}$. All are from 49-5117, $915 \mathrm{~m}$.

Moderately secondarily reticulate form: female left valve (USNM 483937), length $1.45 \mathrm{~mm}$, height $0.97 \mathrm{~mm}$, female right valve (USNM 483938), length $1.45 \mathrm{~mm}$, height $0.87 \mathrm{~mm}$; holotype male left valve (USNM 483939), length $1.53 \mathrm{~mm}$, height $0.97 \mathrm{~mm}$; male right valve (USNM 483940), length $1.83 \mathrm{~mm}$, height $0.87 \mathrm{~mm}$. Female length range: $1.30-1.45 \mathrm{~mm}$, average $1.41 \mathrm{~mm}$; male length range $1.38-1.52 \mathrm{~mm}$, average $1.46 \mathrm{~mm}$. All are from the type locality.

Extensively secondarily reticulate form: female left valve (USNM 483941), length $1.42 \mathrm{~mm}$, height $0.95 \mathrm{~mm}$; female right valve (USNM 483942), length $1.53 \mathrm{~mm}$, height $0.97 \mathrm{~mm}$; male left valve (USNM 483943), length $1.45 \mathrm{~mm}$, height $0.92 \mathrm{~mm}$; male right valve (USNM 483944), length $1.53 \mathrm{~mm}$, height $0.87 \mathrm{~mm}$. Female length range: $1.33-1.45 \mathrm{~mm}$, average $1.38 \mathrm{~mm}$; 


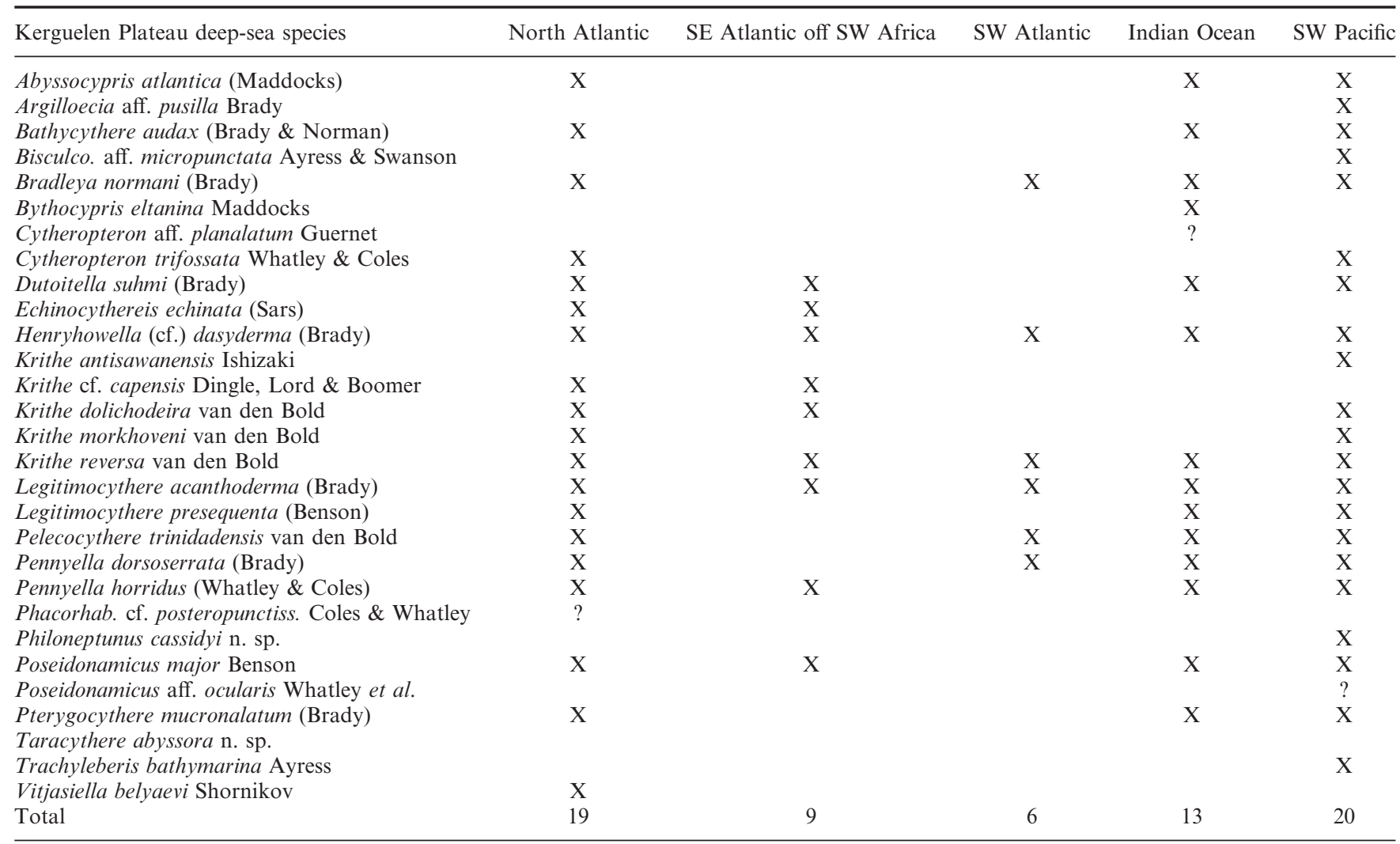

Table 4. Occurrence of deep-water Kerguelen Plateau Ostracoda in the Quaternary and Recent of other deep-sea areas.

male length range $1.37-1.53 \mathrm{~mm}$, average $1.45 \mathrm{~mm}$. All are from 60-5136, $2322 \mathrm{~m}$.

Type locality. Kerguelen Plateau, Eltanin cruise 47, station 44, sample 5112, lat. $53^{\circ} 21.09^{\prime} \mathrm{S}$, long. $71^{\circ} 18.21^{\prime} \mathrm{E}$, water depth $1902 \mathrm{~m}$.

Description. Carapace large, well-calcified without eye tubercle; right valve outline sub-rectangular, left valve outline subtriangular, males more elongate than females. Anterior margin weakly convex above mid-height, strongly convex below with approximately 10 prominent marginal spines. Posterior margin asymmetrically convex with ventral apex bearing about five prominent marginal spines. Dorsal margin steeply inclined to a high anterior hinge ear; ventral margin straight. Subcentral tubercle weak. Short but prominent, arcuate 'ocular' ridge links with a long, continuous anterior and ventro-lateral ridge at the anterior hinge ear; the latter ridge has spinose posterior termination. A shorter dorsal ridge extends close to margin posteriorly where it is prominent and continues ventrally to about midheight just posterior of a short median ridge. Inter-ridge areas primarily and variably secondarily reticulate, muri of the former often weak away from ridges. Internal features typically trachyleberid with holamphidont hinge and undivided subcentral muscle scars.

Distribution. This species is recorded over a wide depth range $(457-3150 \mathrm{~m})$ on the Kerguelen Plateau. However, it is only common or abundant between $747 \mathrm{~m}$ and $2322 \mathrm{~m}$, suggesting it is an outer shelf to slope species. The findings here represent the first modern record of the genus Philoneptunus outside the Australasian and SW Pacific area.

Philoneptunus cassidyi has also been recorded in the Pleistocene of DSDP Sites 206, 208 and 284 (present-day water depths $3196 \mathrm{~m}, 1545 \mathrm{~m}$ and $1066 \mathrm{~m}$, respectively) west of New Zealand (Whatley et al., 1992); off southeast Australia, in Late Pleistocene cores at water depths $2346 \mathrm{~m}$ and $3552 \mathrm{~m}$ (seen by MA in the unpublished MSc. thesis material of Passlow, 1994) and in coretop and sediment surface grab samples on the Chatham Rise at water depths between $800 \mathrm{~m}$ and $1400 \mathrm{~m}$ (pers. comm. H. Neil, 1993). A similar species has also been recorded from Miocene ODP site 689, Maude Rise, Antarctica (Majoran \& Dingle, 2002).

Remarks. Although always at least partially secondarily reticulate, the degree of fossal subdivision and strength of primary muri of this species is variable. Through its upper depth range, between $457 \mathrm{~m}$ and $1110 \mathrm{~m}$, the species is distinctly smaller and subdivision of the reticulation is minimal ( $\mathrm{Pl}$. 2, figs 1-3). At and below $1110 \mathrm{~m}$ a larger form occurs which may be moderately secondarily reticulate (P1. 2, figs 7 and 8 ) or densely so (P1. 2, figs 9-11). Philoneptunus paragravezea Whatley et al. (1992), described from deep water surrounding Australia and New Zealand, is very similar. That species differs from $P$. cassidyi, however, in having secondary reticulation confined to anterior and posterior fields and its median ridge is more robust. 

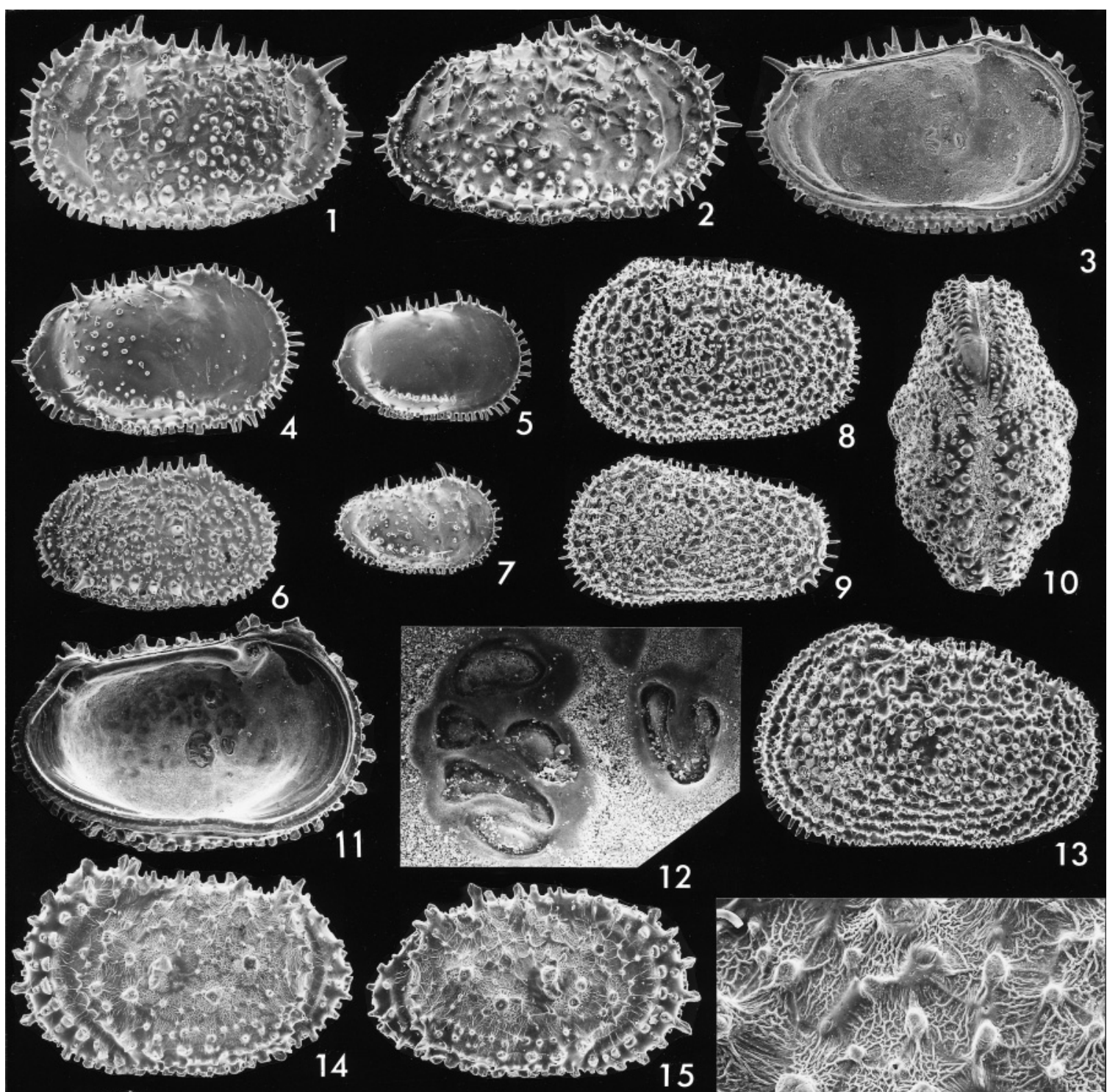

12
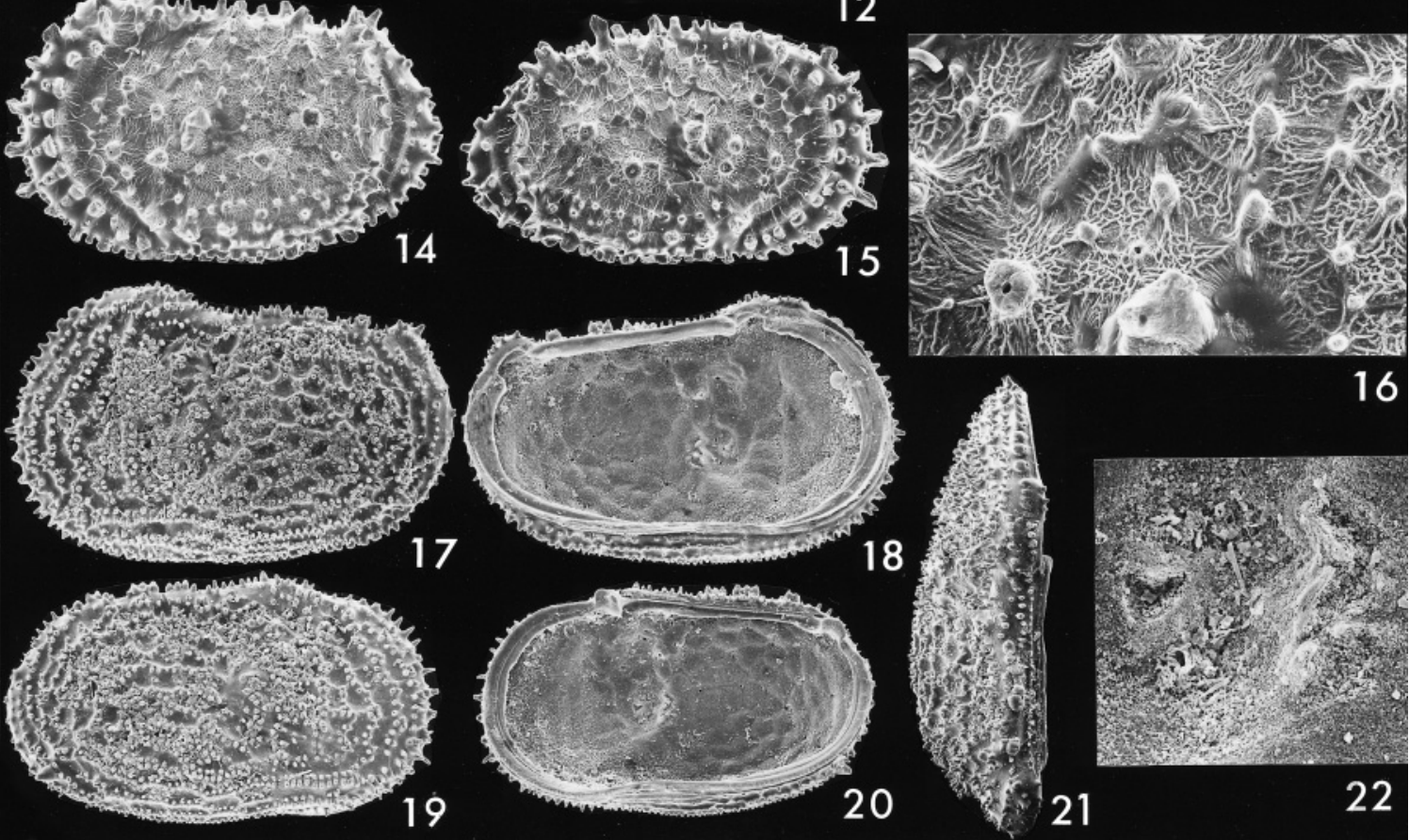
Philoneptunus gravezea (Hornibrook) recorded from the Oligocene to Recent of New Zealand, could be confused, especially with the smaller, weakly secondarily reticulate form of this species and is clearly closely related. Philoneptunus gravezea differs mainly in its eye tubercle and lack of fossal subdivision.

\section{Genus Taracythere Ayress, 1995 \\ Taracythere abyssora $\mathrm{n}$. sp. \\ (Pl. 1, figs 17-22)}

Derivation of name. Latin. Referring to the abyssal distribution of this species.

Diagnosis. A large species of Taracythere with short spines, often paired, closely spaced on muri of polygonal reticulation.

Material. Eight adult valves.

Type material and dimensions. Holotype adult female left valve (USNM 483901), length $0.85 \mathrm{~mm}$, height $0.53 \mathrm{~mm}$; adult female right valve (USNM 483902), length $0.83 \mathrm{~mm}$, height $0.48 \mathrm{~mm}$.

Type locality. Kerguelen Plateau, Eltanin cruise 47, station 12, sample 5069, lat. $51^{\circ} 14.04^{\prime} \mathrm{S}, 7^{\circ}{ }^{\circ} 44.86$ 'E, water depth $3277 \mathrm{~m}$.

Description. Carapace large, sub-ovate in lateral view, with weakly rimmed and denticulate, evenly convex anterior and posterior margins; ventral margin gently convex with very slight oral incurvature. Dorsal margin straight to slightly convex with distinct hinge-ears. Inflation tumid postero-ventrally, anterior somewhat compressed. Surface covered with polygonal reticulation bearing densely crowded short mural spines. Muri are aligned sub-parallel to margins anteriorly and ventrally and the spines in these regions are usually paired. A distinct stout spine occurs close to margin postero-ventrally. Normal pores very small emergent at centre of spine clusters. Inner lamella narrow, without vestibule. Radial pore canals straight, about 21 true canals anteriorly, nine posteriorly. Hinge holamphidont. Subcentral muscle scars undivided, typically trachyleberid.

Distribution. Only presently known from the Kerguelen Plateau at abyssal depths between $3150 \mathrm{~m}$ and $3584 \mathrm{~m}$.

Remarks. This is the first record of the genus outside the western Pacific region. The new species has the distinctively upswung posterior margin and prominent postero-ventral spine charac- teristic of Taracythere (Ayress, 1995). Among the Taracythere species described by Ayress (1995) T. abyssora is most similar to $T$. conjunctispinosa, but $T$. abyssora has a more even and densely spinose ornament than the latter species, distinct from the web-like reticulation and conjunctive spines of $T$. conjunctispinosa. 'Cythere' melobesoides Brady of Nohara (1987) from Okinawa-Jima also belongs to Taracythere but to a separate species which differs from $T$. abyssora mainly in its fewer and stronger spines.

\section{TAXONOMIC NOTES ON OTHER OSTRACOD SPECIES}

Vitjasiella belyaevi Schornikov, 1976 (PI. 3, fig. 1)

Brady (1880) may have included this species in Vitjasiella fenestrata (Brady, 1880) and originally recorded at two stations: 149 (274 m off Kerguelen Island) and 335 (2606 $\mathrm{m}$ in the central South Atlantic). Puri \& Hulings (1976) selected a lectotype from Brady's station 149. The material here differs from the lectotype of $V$. fenestrata in being considerably larger, length $1.37 \mathrm{~mm}$ (lectotype is $0.93 \mathrm{~mm} \times 0.56 \mathrm{~mm}$ ) and having a less angular dorsal margin. This species has been reported from the northwestern Pacific, between $5090 \mathrm{~m}$ and $5200 \mathrm{~m}$ (Schornikov, 1976, 1981) and the authors (MA, GC) have seen it in the material of Barkham (ms, 1985) off northwest Africa between $1775 \mathrm{~m}$ and $3083 \mathrm{~m}$. Thus, both species appear to occur on the Kerguelen Plateau.

\section{Cluthia sp. (PI. 4, fig. 7)}

Ayress \& Drapala (1996) recorded six species of Cluthia from the Late Eocene to Recent of Australasia, a genus better known from cold waters of the Northern Hemisphere. The material here is closest to Cluthia micra and Cluthia sp. 2 of Ayress \& Drapala (1996), but seems to differ from all species of the genus in its continuous posterior ridge uniting dorsal and vento-lateral ridges. The present record further indicates the bihemispheric distribution of the genus.

Pterygocythere mucronalatum (Brady, 1880) (Pl. 3, fig. 3)

This cosmopolitan abyssal species usually has a smooth valve exterior surface. The specimens here are finely reticulate on the posterior half of the valve surface, but in all other respects they conform to the species. Some workers place this species within Bosquetina Keij, 1957. Its similarity with that genus seems to be rather superficial, however, since there are clear internal differences from Bosquetina in the present species, notably the accommodation groove, two frontal scars and a prominent anterior median hinge tooth. It appears to be closer to Pterygocythere,

\section{Explanation of Plate 1.}

figs 1-5. Bathycythere audax (Brady \& Norman): 1, 42-5110, $2725 \mathrm{~m}$, length $1.58 \mathrm{~mm}$, female left valve (USNM 483903) external lateral view; 2, 44-5112, $1902 \mathrm{~m}$, length $1.57 \mathrm{~mm}$, female right valve (USNM 483904) external lateral view; 3, 42-5110, length $1.58 \mathrm{~mm}$, female left valve (USNM 483903 ) internal lateral view; 4, 42-5110, length $1.26 \mathrm{~mm}$, penultimate instar right valve (USNM 483905) external lateral view; 5, 42-5110, length $0.87 \mathrm{~mm}$, early instar right valve (USNM 483906) external lateral view. figs 6-7. Legitimocythere acanthoderma (Brady), both from 42-5110, 2725 m: 6, length $1.17 \mathrm{~mm}$, female right valve (USNM 483899) external lateral view; 7, length $0.74 \mathrm{~mm}$, early instar right valve (USNM 483900) external lateral view. figs 8-10. Henryhowella sp.: 8, 50-5120, $747 \mathrm{~m}$, length $0.85 \mathrm{~mm}$, female left valve (USNM 483929) external lateral view; 9, 50-5120, length $0.77 \mathrm{~mm}$, male left valve (USNM 483930) external lateral view; 10, 56-5130, $280 \mathrm{~m}$, length $0.87 \mathrm{~mm}$, female carapace (USNM 483931) dorsal view. figs 11-12, 14-16. Legitimocythere presequenta (Benson), all from sample 58-5133, $3150 \mathrm{~m}$ : length $1.03 \mathrm{~mm}$, adult left valve (USNM 483909); 11, internal lateral view; 12, subcentral muscle scars; 14, external lateral view; 16, external surface detail; 15, length $1.02 \mathrm{~mm}$, adult right valve (USNM 483910) external lateral view. fig. 13. Henryhowella $\mathrm{cf}$. H. dasyderma (Brady), 56-5116, $1110 \mathrm{~m}$, length $0.85 \mathrm{~mm}$, female left valve (USNM 483932) external lateral view. figs 17-22. Taracythere abyssora $\mathrm{n}$. sp., all from sample 12-5069, $3277 \mathrm{~m} ; \mathbf{1 7}-\mathbf{1 8}, \mathbf{2 1}$, length $0.85 \mathrm{~mm}$, holotype adult left valve (USNM 483901): 17, external lateral view; 18, internal lateral view; 21, dorsal view; 19-20, 22, length 0.83 mm, adult right valve (USNM 483902): 19, external lateral view; 20, internal lateral view; 22, subcentral muscle scars. 


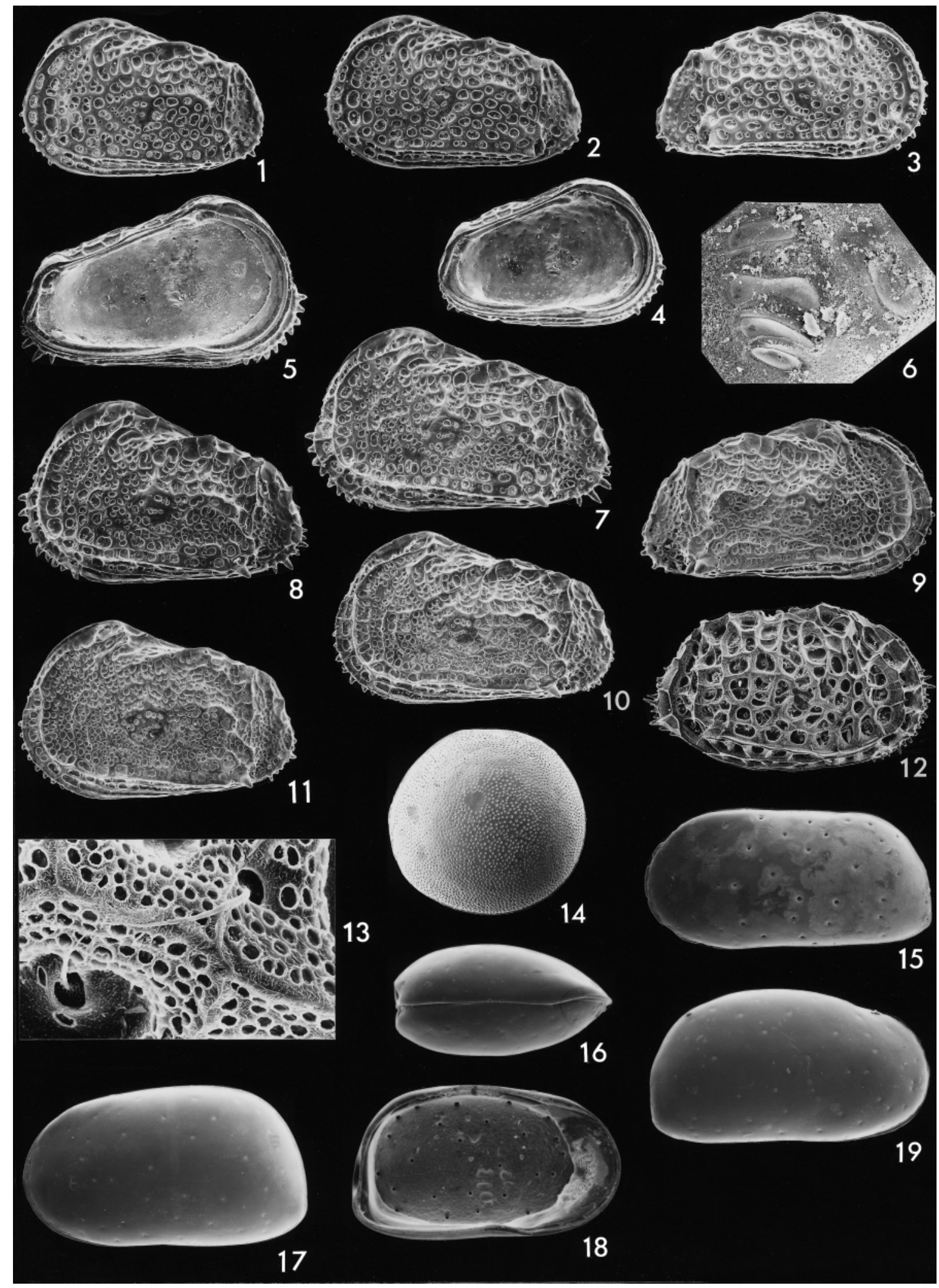


differing from that genus only in lacking an eyespot, and was assigned to Pterygocythere by Coles et al. (1990), Whatley \& Coles (1991) and Cronin (1996). Stratigraphical considerations also suggest a closer relationship to Pterygocythere as the oldest occurrence of $P$. mucronalatum is in the Early Palaeocene of the North Atlantic (Whatley \& Coles, 1991) and the genus Pterygocythere is well known from the Late Cretaceous (Coles et al., 1990), whereas Bosquetina is confined to the Oligocene to Recent in relatively shallow-marine sediments. Guernet \& Moullade (1994) propose a new genus, Pseudobosquetina, for this species on the basis of hingment that, in the authors' opinion, is insufficient to support separation at the generic level.

Cytheropteron aff. C. planalatum Guernet, 1985 (PI. 3, figs 4-6) This species is closely related to a group of species, many of which are yet to be described (see for example Cytheropteron sp. 1 Ayress, 1994, fig. 12; and Cytheropteron sp. 1 Ayress, 1996, pl. 1, fig. 12), from the Indo-Pacific. Cytheropteron planalatum Guernet, 1985, from the Upper Eocene of DSDP Site 214, is typical of the group and the present species differs from it in having coarser punctation and in lacking dorsal ridges. It is similar to an Antarctic species erroneously referred by various authors (e.g. Neale, 1967) to Cytheropteron abyssorum Brady (1880) and well illustrated by Whatley et al. (1988, pl. 3, figs 5-7). That species is confined to shallow water and differs from the present species, and from C. abyssorum sensu stricto, in having an eyespot, and a more rhomboidal lateral outline (Passlow \& Ayress, 1994).

\section{Cytheropteron perlaria Hao, 1988 (Pl. 3, figs 7-8)}

Following the review of Swanson \& Ayress (1999), the material here is referred to Cytheropteron perlaria rather than the very similar species Cytheropteron testudo Sars, based on the weaker alar process and more triangular shape of $C$. perlaria. In the material here, $C$. perlaria is confined to relatively shallow-water depths between $110 \mathrm{~m}$ and $457 \mathrm{~m}$ and is only common at $110 \mathrm{~m}$. The deep-sea global distribution of this species today indicates its preference for cold water (Swanson \& Ayress, 1999), and its record here in Antarctic waters is consistent with this observation. It has also been found in Antarctica at $330 \mathrm{~m}$ in the Ross Sea (Briggs, 1978) and living at $434 \mathrm{~m}$ on the MacRobertson Shelf (pers. comm. A. Rathburn, 1994).

Krithe antisawanensis Ishizaki, 1966 (Pl. 2, figs 15-19; Fig. 9A) The Antarctic species Krithe magna (Hartmann, 1986), described from female valves as Profundocythere magna, resembles $K$. antisawanensis in valve shape and in the relatively narrow inner lamella, but has a much larger anterior vestibule. Krithe magna (Hartmann) illustrated by Whatley et al. (1998) from 1555 $3925 \mathrm{~m}$ water depth in the Scotia Sea resembles the material here in size and sexual dimorphism, although the specimens of Whatley et al. differ in shape, especially in the more arched dorsal margin of the male valve. Krithe dilata Ayress et al. (1999), described from the Early Pliocene to Recent of the Tasman Sea, is rather similar in valve shape, but has a much larger, distally expanded anterior vestibule. Amongst the present material, $K$. antisawanensis most closely resembles $K$. cf. $K$. capensis Dingle et al. (1990), although the posterior is more truncate in the present species, and the anterior vestibulae of the two species differ in size and shape.

This species is restricted in the material here to four samples ranging from $280-915 \mathrm{~m}$; it is common only at $747 \mathrm{~m}$. Ayress et al. (1999) recorded Krithe antisawanensis from the Middle Miocene (NN6) to Recent of the Tasman Sea off Southern Australia, in water depths ranging from 686-3403 m. Zhou \& Ikeya (1992) report this species from the Miocene to Pleistocene of Japan and from 150-600 m water depth in Suruga Bay, Japan.

\section{Krithe cf. K. capensis Dingle et al., 1990 (Pl. 4, figs 5-10; Fig. 9C)}

In valve size and shape, particularly the rather narrowly convex and somewhat upturned anterior margin, and in the form of the anterior vestibulum, this species is comparable to $K$. capensis Dingle et al., 1990. However, a firm identification of the current material with $K$. capensis is not made as the Kerguelen specimens are less prominently postero-dorsally arched than $K$. capensis. In addition, the material here displays strong sexual dimorphism, but Dingle et al. do not allude to this in their treatment of the species. Krithe sp. 19 of Coles et al. (1994) closely resembles the material here and is considered conspecific, although the anterior vestibule in the Kerguelen specimens is rather smaller. Krithe sp. from $274 \mathrm{~m}$ in Sulzberger Bay, Ross Sea (Benson, 1964) probably also belongs to this species, although the muscle scar pattern illustrated by Benson, if correct, does not match the specimens here. This species is separated from the similar $K$. antisawanensis in the material here by virtue of its more gently truncate posterior margin and larger mushroom-shaped anterior vestibulum.

Krithe sp. cf. $K$. capensis is recorded over a wide depth range between $600 \mathrm{~m}$ and $3584 \mathrm{~m}$ on the Kerguelen Plateau, where it is locally common, most notably at $1587 \mathrm{~m}$. Krithe capensis was

Explanation of Plate 2.

figs 1-11. Philoneptunus cassidyi $\mathrm{n}$. sp: 1-4, weakly secondary reticulate form, all from 49-5117, $915 \mathrm{~m}$; 1, length $1.25 \mathrm{~mm}$, female left valve (USNM 483934) external lateral view; 2 , length $1.33 \mathrm{~mm}$, male left valve (USNM 483935) external lateral view; 3, length $1.32 \mathrm{~mm}$, male right valve (USNM 483936) external lateral view; 4, length $1.25 \mathrm{~mm}$, female left valve (USNM 483934) internal lateral view; $\mathbf{5 - 8}$, moderately secondary reticulate form, all from 44-5112, $1902 \mathrm{~m} ; \mathbf{5}-\mathbf{7}$, length $1.53 \mathrm{~mm}$, holotype male left valve (USNM 483939); 5, internal lateral view; 6 , subcentral muscle scars; 7, external lateral view; 8, length $1.45 \mathrm{~mm}$, female left valve (USNM 483937) external lateral view; 9-11, extensively secondary reticulate form, all from 60-5136, $2322 \mathrm{~m}$; 9, length $1.53 \mathrm{~mm}$, male right valve (USNM 483944) external lateral view; 10, length $1.45 \mathrm{~mm}$, male left valve (USNM 483943) external lateral view; 11, length $1.1 .42 \mathrm{~mm}$, female left valve (USNM 483941) external lateral view. figs 12-13. Bradleya normani (Brady): 4-5056, $600 \mathrm{~m}$; length $0.90 \mathrm{~mm}$, female right valve (USNM 483920): 12, external lateral view; 13, detail of mural ornament, and intact pore setae suggesting minimal post-mortem transport. fig. 14. Polycope sp. 13-5072, $3584 \mathrm{~m}$; length $1.32 \mathrm{~mm}$, adult (USNM 483945) external lateral view. figs 15-19. Krithe antisawanensis Ishizaki, all from 50-5120, $747 \mathrm{~m}$ : 15, length $0.95 \mathrm{~mm}$, male left valve (USNM 483952) external lateral view; 16, length $0.82 \mathrm{~mm}$, female carapace (USNM 483953) dorsal view; 17-18, length $0.95 \mathrm{~mm}$, female left valve (USNM 483954); 17, external lateral view; 18, internal lateral view; 19, length $0.94 \mathrm{~mm}$, female right valve (USNM 483955). 


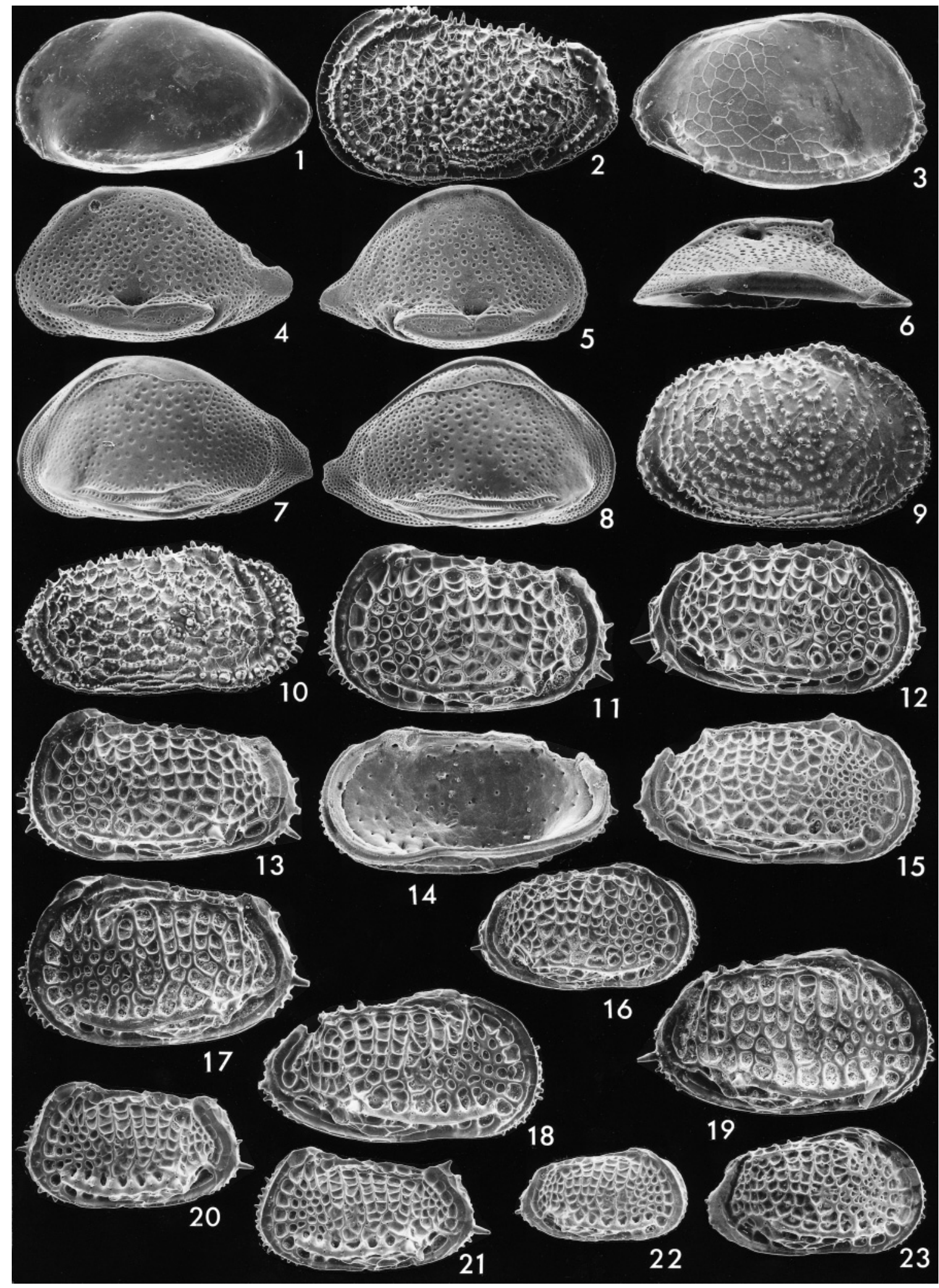


recorded from 238-1430 m off southwestern Africa by Dingle et al. (1990) and was considered the dominant species on the continental shelf and uppermost slope. Coles et al. (1994) recorded this species as Krithe sp. 19 rarely in the Quaternary (NN19-21) of DSDP Hole 606A in the North Atlantic.

\section{Krithe dolichodeira van den Bold, 1946 (Pl. 5, figs 11-16; Fig. 9D)}

The Kerguelen specimens in this study and supplementary material from the Drake Passage (Eltanin Cruise 43, 52 $38^{\circ} \mathrm{S}$, $75^{\circ} 25^{\prime} \mathrm{W}, 787 \mathrm{~m}$ ) conform to $K$. dolichodeira in all respects except size; the length of that species is usually less than $0.90 \mathrm{~mm}$, according to Coles et al. (1994). The slight size difference between the Kerguelen and the North Atlantic material is not considered to warrant any specific distinction. Abate et al. (1993) demonstrate that Krithe compressa (Seguenza, 1880), previously considered by Coles et al. (1994) as a possible senior synonym of $K$. dolichodeira is actually a senior synonym of $K$. aequabilis Ciampo, 1986.

Krithe dolichodeira is present at $787 \mathrm{~m}$ and is rare to moderately common between $1404 \mathrm{~m}$ and $3150 \mathrm{~m}$ on the Kerguelen Plateau. It is very widely distributed in the Lower Eocene (NP 10) to Recent from localities in the Atlantic, Caribbean and Meditteranean (Coles et al. 1994) and in the Late Miocene to Recent of the Tasman Sea between $686 \mathrm{~m}$ and $3281 \mathrm{~m}$ (Ayress et al. 1999).

\section{Krithe morkhoveni van den Bold, 1960 (Pl. 5, figs 17-23; Fig. 9E)}

Although the Kerguelen material is rather larger than $K$. morkhoveni from the North Atlantic (comparing dimension ranges given in Coles et al., 1994), the shape of the anterior vestibule, inner lamella and details of the lateral outline conform with the range of variation seen in $K$. morkhoveni. Relatively large size appears to be a consistent phenomenon among the Krithe species of this study compared with other regions; this may be a function of low water temperatures represented by the material here.

Krithe morkhoveni is recorded from three samples between $1045 \mathrm{~m}$ and $1587 \mathrm{~m}$, but is only common at $1110 \mathrm{~m}$. This species is very widely recorded from the Lower Eocene (NP 10) to Recent of the Atlantic and adjacent onshore areas (Coles et al. 1994).
Ayress et al. (1999) report $K$. morkhoveni from the Lower Pliocene (NN 15) to Recent of the Tasman Sea and Australian continental slope between $804 \mathrm{~m}$ and $3552 \mathrm{~m}$.

\section{Krithe cf. K. praetexta (Sars, 1866) (PI. 5, figs 1-4; Fig. 9B)}

The carapace morphology matches very closely $K$. praetexta (Sars), a common northwest European shelf species recently reviewed and illustrated by Abate et al. (1993). However, the more bluntly truncate posterior margin and somewhat larger size (Northern Hemisphere forms rarely exceed $0.90 \mathrm{~mm}$ in length) of the specimens here suggest that the Kerguelen material may be separable.

This species was only found in two samples: it is common at $425 \mathrm{~m}$ but is represented by a single, possibly transported, valve at $747 \mathrm{~m}$. Krithe praetexta is known from the shelf sediments in the Quaternary and Recent of northwest Europe and Mediterranean and Upper Pliocene to Quaternary of Sicily (Abate et al., 1993; G. Coles, pers. obs.).

\section{Krithe reversa van den Bold, 1958}

This cosmopolitan deep-water Krithe species is easily identified by its reversed $(\mathrm{RV}>\mathrm{LV})$ overlap, large size, strong sexual dimorphism and anterior radial pore canal pattern. In China and Japan this species has usually been recorded as Krithe sawanensis Hanai, 1959. In the material here Krithe reversa was sporadically recorded in the deeper waters of the Kerguelen Plateau between $1902 \mathrm{~m}$ (where it is abundant) and $3584 \mathrm{~m}$ (the deepest analysed sample). Two valves are also noted at $915 \mathrm{~m}$. The species is cosmopolitan in the deep sea from the Middle Miocene (NN 6) to Recent and most typical of waters of $1000 \mathrm{~m}$ or deeper (Coles et al., 1994). Zhou \& Whatley (1997) record $K$. reversa between $640 \mathrm{~m}$ and $2054 \mathrm{~m}$ in the East China Sea, while Ayress et al. (1999) record it from the Lower Pliocene (NN 13) to Recent of the East Tasman Sea.

\section{Bradleya normani (Brady, 1865) (Pl. 2, figs 12, 13)}

Whatley \& Coles (1991) record Bradleya normani from the Late Quaternary (NN 21) and Recent of the North Atlantic. Whatley et al. $(1996,1997)$ report $B$. normani in shallow water depths from $9.3-527 \mathrm{~m}$ in the southern Strait of Magellan and attribute the occurrence of this and other typical psychrospheric species to the very cold temperatures and the upwelling of cold, deep

\footnotetext{
Explanation of Plate 3.

fig. 1. Vitjasiella belyaevi Schornikov, 13-5072, $3584 \mathrm{~m}$, length $1.37 \mathrm{~mm}$, adult left valve (USNM 483928) external lateral view. fig. 2. Pennyella dorsoserrata (Brady), 42-5110, $2725 \mathrm{~m}$, length $0.87 \mathrm{~mm}$, male? left valve (USNM 483946) external lateral view. fig. 3. Pterygocythere mucronalatum (Brady), 58-5133, $3150 \mathrm{~m}$, length $1.40 \mathrm{~mm}$, adult right valve (USNM 483926) external lateral view. figs 4-6. Cytheropteron aff. C. planalatum Guernet, all from sample 8-5063, $1587 \mathrm{~m}:$ 4, length $0.80 \mathrm{~mm}$, adult left valve (USNM 483897) external lateral view; 5-6, length 0.78 mm, adult right valve (USNM 483898); 5, external lateral view; 6, dorsal view. figs 7-8. Cytheropteron perlaria Hao, both from sample 2-5046, $110 \mathrm{~m}$ : 7, length $0.58 \mathrm{~mm}$, adult left valve (USNM 483895) external lateral view; 8, length $0.57 \mathrm{~mm}$, adult right valve (USNM 483896) external lateral view. fig. 9. Echinocythereis echinata (Sars), 11-5068, $2306 \mathrm{~m}$, length $1.40 \mathrm{~mm}$, female right valve (USNM 483947) external lateral view. fig. 10. Trachyleberis bathymarina Ayress, 49-5117, $915 \mathrm{~m}$, length $1.20 \mathrm{~mm}$, male right valve (USNM 483948) external lateral view. figs 11-16. Poseidonamicus aff. P. ocularis Whatley et al.: 11, 7-5062, $1404 \mathrm{~m}$, length $1.03 \mathrm{~mm}$, female left valve (USNM 483911) external lateral view; 12, 45-5113, 1701 m, length $1.05 \mathrm{~mm}$, female right valve (USNM 483912) external lateral view; 13, 7-5062, $1404 \mathrm{~m}$, length $1.05 \mathrm{~mm}$, male left valve (USNM 483914) external lateral view; 14-15, 41-5109, $2970 \mathrm{~m}$, length $1.10 \mathrm{~mm}$, male right valve, form with anterior punctation (USNM 483913); 14, internal lateral view, 15, external lateral view; 16, 7-5062, $1404 \mathrm{~m}$, length $0.85 \mathrm{~mm}$, juvenile right valve (USNM 483915) external lateral view. figs 17-19, 23. Poseidonamicus major Benson, all from sample 42-5110, $2725 \mathrm{~m}$ : 17, length $1.05 \mathrm{~mm}$, female left valve (USNM 483916) external lateral view; 18, length 1.08 mm, male right valve (USNM 483918) external lateral view; 19, length $1.05 \mathrm{~mm}$, female right valve (USNM 483917) external lateral view; 23, length $0.85 \mathrm{~mm}$, juvenile right valve (USNM 483919) external lateral view. figs 20-22. Poseidonamicus ocularis? Whatley et al., all from East Tasman Plateau 'Franklin' cruise 1/94 grab sample, $1900 \mathrm{~m}$ : 20, length $0.84 \mathrm{~mm}$, female left valve (ANU 49449) external lateral view; 21, length $0.85 \mathrm{~mm}$, male left valve (ANU 49448) external lateral view; 22, length $0.65 \mathrm{~mm}$, juvenile right valve (ANU 49452) external lateral view.
} 


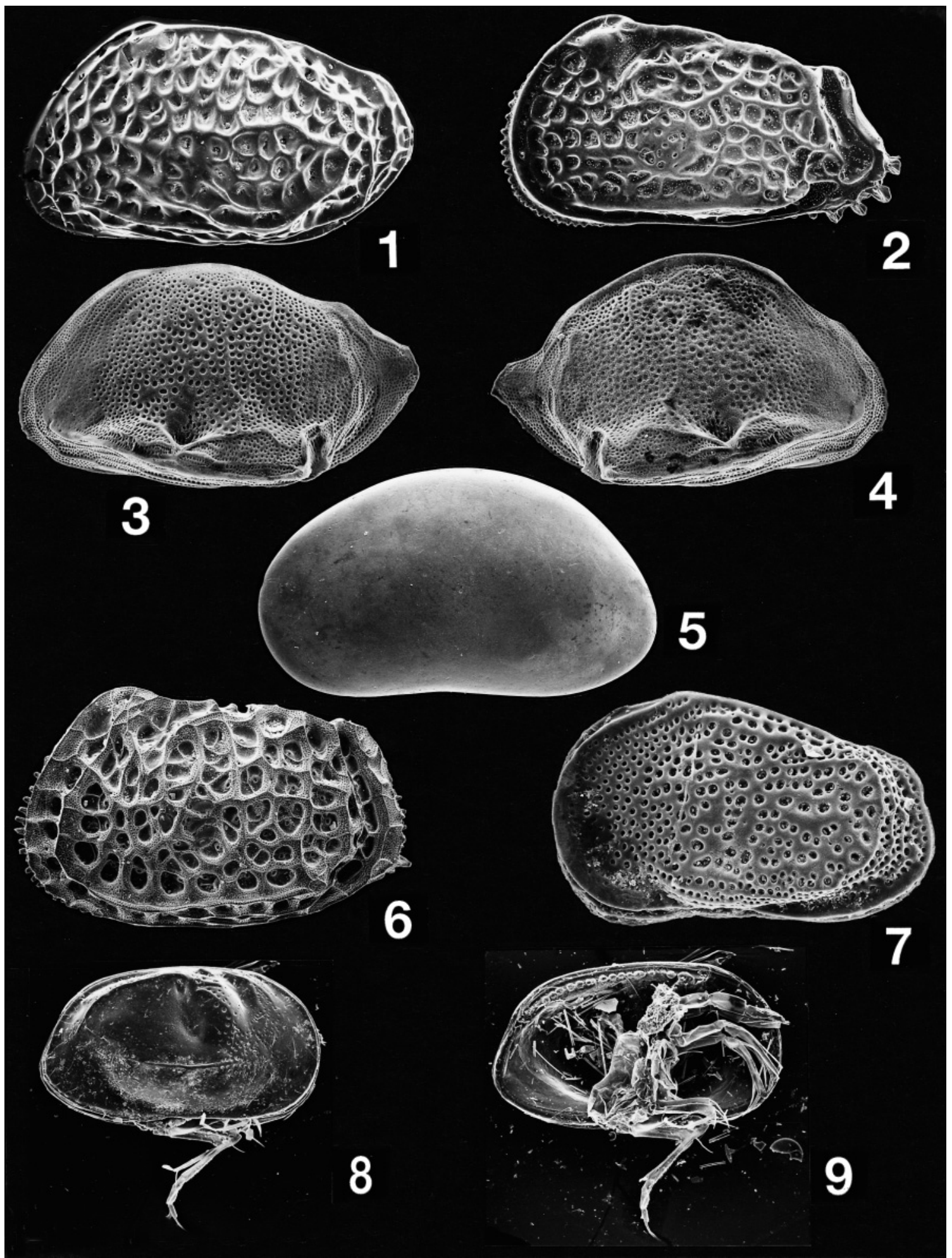

Explanation of Plate 4.

fig. 1. Loxoreticulatum fallax (Muller), 2-5046, $110 \mathrm{~m}$, length $0.55 \mathrm{~mm}$, female left valve (USNM 483951). fig. 2. Patagonacythere wyvillethomsoni (Brady), 53-5124, $216 \mathrm{~m}$, length $0.87 \mathrm{~mm}$, female left valve (USNM 483949). figs 3-4. Cytheropteron aff. antarctica Chapman: 3, 54-5126, 425 m, length $0.62 \mathrm{~mm}$, adult left valve (USNM 483924); 4, 54-5126, $425 \mathrm{~m}$, length $0.62 \mathrm{~mm}$, adult right valve (USNM 483925). fig. 5. Bythocypris reniformis Brady, 54-5126, $425 \mathrm{~m}$, length $1.43 \mathrm{~mm}$, female left valve (USNM 483950). fig. 6. Bradleya normani (Brady), 56-5130, $280 \mathrm{~m}$, length 0.92 mm, female left valve (USNM 483921). fig. 7. Cluthia sp., 2-5046, $110 \mathrm{~m}$, length $0.37 \mathrm{~mm}$, adult carapace (USNM 483894) left lateral view. figs 8-9. Bisulcocythere cf. micropunctata Ayress \& Swanson, both from 4-5056, $600 \mathrm{~m}$, length $0.69 \mathrm{~mm}$ : 8, male carapace, right external lateral view (USNM 483907); 9, same specimen with right valve removed to show internal mummified soft-parts. 

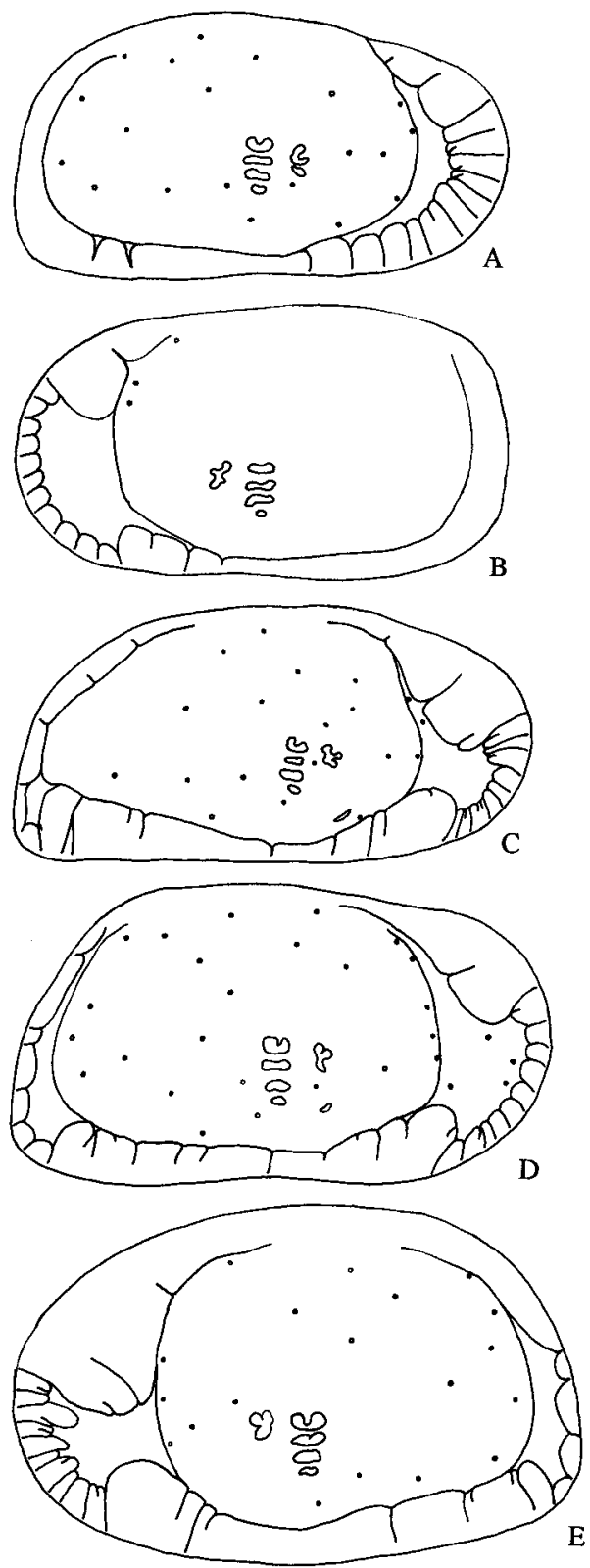

Fig. 9. Internal features of Krithe seen in external view using transmitted light. (A) Krithe antisawanensis Ishizaki, 50-5120, length $0.94 \mathrm{~mm}$, female right valve (USNM 483955). (B) Krithe cf. K. praetexta (Sars), 54-5126, length $0.95 \mathrm{~mm}$, adult left valve (USNM 483956). (C) Krithe cf. $K$. capensis Dingle et al., 50-5120, length $1.00 \mathrm{~mm}$, male right valve (USNM 483960). (D) Krithe dolichodeira van den Bold, Eltanin 43, $787 \mathrm{~m}$, length $1.04 \mathrm{~mm}$, female right valve (USNM 483962). (E) Krithe morkhoveni van den Bold, 48-5116, length $1.09 \mathrm{~mm}$, female left valve (USNM 483964).

watermasses. Briggs (1978) recorded this species from the Late Pleistocene Taylor Formation of Ross Island, Antarctica in a predominantly shallow-marine ostracod assemblage.

The species has a considerable depth range on the Kerguelen Plateau, occurring from $215 \mathrm{~m}$ to $3584 \mathrm{~m}$ and is present in most $(67 \%)$ of the samples. In the material here, eye tubercles are large in this species down to a depth of $457 \mathrm{~m}$, reduced in size down to
$613 \mathrm{~m}$ and absent at and below $747 \mathrm{~m}$. Internal soft-parts and pore setae are occasionally seen intact (Pl. 2, fig. 13). It is superabundant at $280 \mathrm{~m}$ and common between $425 \mathrm{~m}$ and $613 \mathrm{~m}$. However, in the deeper-water samples examined between $747 \mathrm{~m}$ and $3584 \mathrm{~m}$ it is, except for the sample at $1587 \mathrm{~m}$, a minor component of the ostracod assemblage. Given the abundance of sighted Bradleya spp. occurring today at shallow depths, it seems likely that the closest ancester of $B$. normani was also sighted and, in this instance, blindness in deeper occurring individuals does not necessarily indicate deep-water ancestry, as has been suggested for some deeper living taxa (Dingle, 2002, 2003).

Poseidonamicus major Benson, 1972 (PI. 3, figs 17-19, 23)

The greater emphasis of vertical muri of the mid-posterior reticulum and a slightly more angular posterior margin distinguish $P$. major from $P$. aff. $P$. ocularis of this study. Juveniles were also distinguished by virtue of their secondarily punctate anterior field (P1. 3, fig. 23).

Poseidonamicus major is confined to the deeper analysed samples on the Kerguelen Plateau, recorded between $1902 \mathrm{~m}$ and $3277 \mathrm{~m}$. Whatley (1985) records only juveniles from the Neogene of Coral Sea and Tasman Sea DSDP sites. Dingle et al. (1990) discuss the stratigraphical and geographical occurrence of $P$. major and record the species off southwestern Africa at $2070 \mathrm{~m}$ and abundantly at $2916 \mathrm{~m}$.

\section{Poseidonamicus aff. P. ocularis Whatley et al., 1986 (PI. 3, figs 11-16)}

In the material here there is variation between a uniformly developed post median reticular field and some tendency for vertical mural alignment and, in this latter respect, the material here shows affinity to $P$. ocularis Whatley et al., 1986. The truncate anterior and posterior margins reported to be diagnostic of $P$. ocularis were sometimes also observed in the material here. In adults an ocular sinus is usually absent but, in juveniles, an ocular sinus is usually present and, externally, a small eye tubercle is sometimes visible. Specimens below a depth of some $2700 \mathrm{~m}$ show a tendency towards subdivision of the anterior punctate field (Pl. 3, fig. 15). Because of the observed differences, especially in the pattern of the reticulation, the material here has been separated from $P$. ocularis s.s., although the authors prefer not to formalize this distinction at present. For comparative purposes, specimens from the East Tasman Plateau (water depth $1900 \mathrm{~m}$, lat. $46^{\circ} 15.08^{\prime} \mathrm{S}$, long. $146^{\circ} 32.49^{\prime} \mathrm{E}$ ), which also have affinities with $P$. ocularis are illustrated (Pl. 3, figs 20-22). Particularly notable are the smaller size and relatively truncate anterior compared to the Kerguelen material. The relationship between these forms and Poseidonamicus major s.s. is unclear at present and awaits a better understanding of the range of variation of each species.

This species is present over a wide depth range (915-3584 m) on the Kerguelen Plateau and is most commonly recorded between $1404 \mathrm{~m}$ and $1902 \mathrm{~m}$.

Bathycythere audax (Brady \& Norman, 1889) (Pl. 1, figs 1-5)

The material is assigned to Bathycythere audax (Brady \& Norman) based on comparison with the illustrations provided 


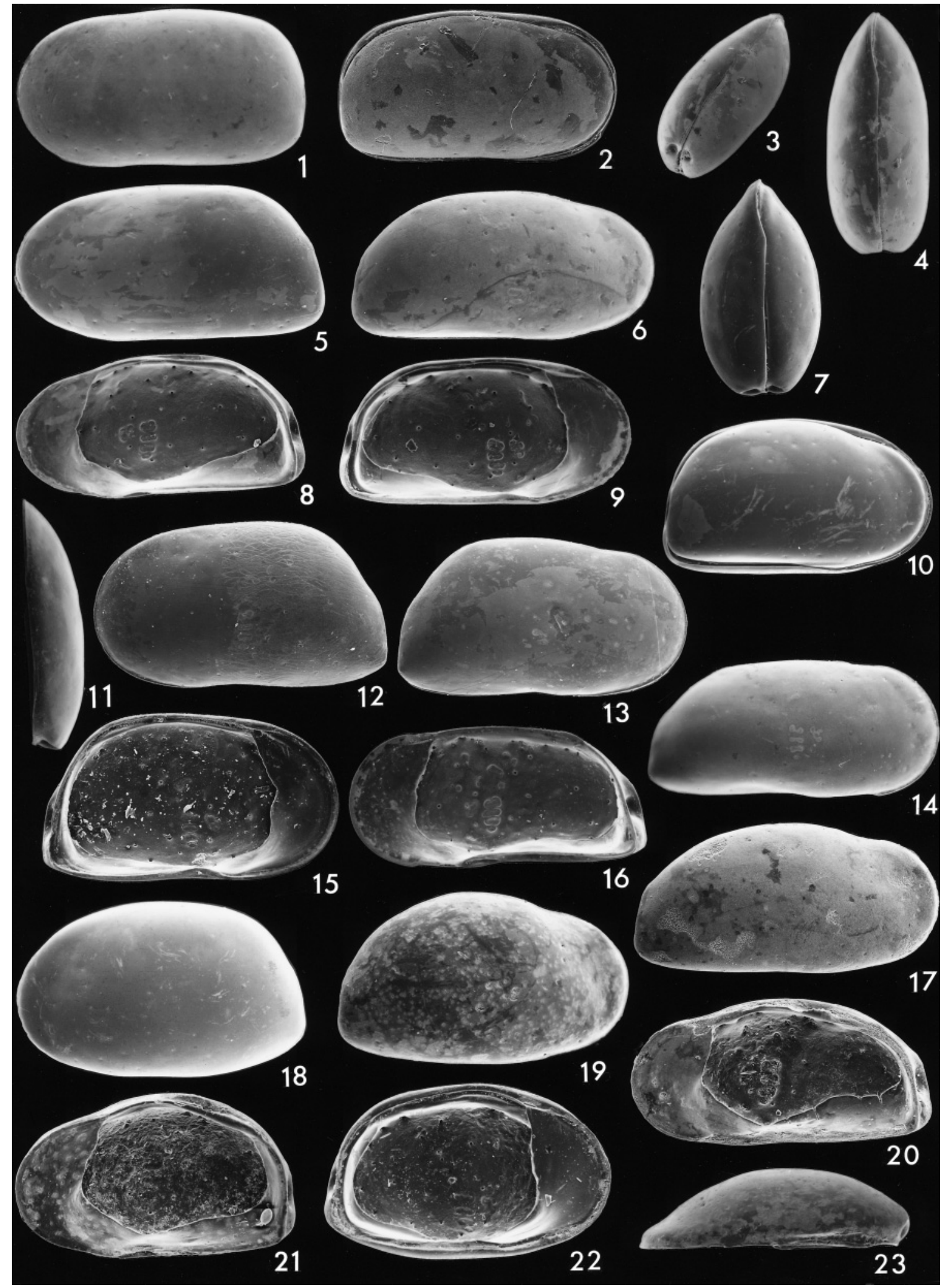


by Brady \& Norman (1889). The degree of spine development in juveniles (Pl. 1, figs 4 and 5) is very similar that seen in the type species, B. vanstraateni Sissingh, 1971 recorded from the Quaternary of the Mediterranean, and western Indian Ocean. Previously, most records of what one recognizes as $B$. audax have been assigned to $B$. vanstraateni, possibly because only juvenile specimens were found. It is observed that the two species can be separated on the basis of the lateral outline: that of $B$. vanstraateni is trapezoid with its maximum length situated ventrally, whereas that of $B$. audax is more ovate with its maximum length at mid-height. In Kerguelen, the reticulation and greater number of spines in adult $B$. audax further serve to distinguish these species. Also in the Kerguelen material, the adductor muscle scars and the ovate frontal scar are never subdivided. Only rarely in some juvenile specimens from the Tasman Sea (Ayress, pers. obs.) does subdivision of the scars approach the condition seen in B. vanstraateni, as illustrated by Sissingh (1974). Ruan (1989, pl. 24, figs 1-3) illustrates a similar form to B. audax collected from $2004 \mathrm{~m}$ and $2120 \mathrm{~m}$ in the South China Sea. However, it is slightly smaller (length around $1.30 \mathrm{~mm}$ ) is somewhat more elongate and has a much stronger subcentral tubercle.

The current material was recorded from the deeper waters of the Kerguelen Plateau between $1902 \mathrm{~m}$ and $3584 \mathrm{~m}$. Bathycythere audax has been documented world-wide from the Middle Miocene to Recent as B. vanstraateni by Whatley \& Coles (1987) and Whatley \& Ayress (1988) and as B. audax by Coles et al. (1990) and Cronin (1996). Judging from the illustrations and size range, Ruan \& Hao (1988) have also found this species (recorded as Acanthocythereis cf. araneosa Howe) in their material from the Okinawa Trough.

\section{Echinocythereis echinata (Sars, 1866) (PI. 3, fig. 9)}

Cythere irpex Brady, 1880 is conspecific with Cythereis echinata Sars, 1866 judging from scanning electron micrograph illustrations supplied by Boomer (lit. comm., 1994) of the lectotype selected by Puri \& Hulings (1976). The current study considers that Echinocythereis whatleyi Dingle et al., 1990 described from 945-2916 m water depth off southwest Africa is based on juveniles of E. echinata (Sars).

Echinocythereis echinata is recorded only from three samples between $2295 \mathrm{~m}$ and $2725 \mathrm{~m}$ in the material here, where it is rare. This species is widely distributed in the Miocene to Recent of the North Atlantic, but only rarely recorded from elsewhere (Coles et al., 1990; Whatley \& Coles, 1991; pers. obs.).
Henryhowella cf. H. dasyderma (Brady, 1880) (Pl. 1, fig. 13)

Deep-sea material of Henryhowella is usually assigned, with varying degrees of confidence, to either $H$. asperrima (Reuss, 1850) or H. dasyderma (Brady, 1880) mainly on the basis of whether or not posterior longitudinal ridges (plications) are present (see Dingle et al., 1990 for discussion of deep-water Henryhowella species). The longitudinal ridges characteristic of $H$. asperrima are only weakly developed in some specimens of the present material at and below $2725 \mathrm{~m}$; consequently the material is referred to $H$. dasyderma. However, because of the juvenile nature of the lectotype (Puri \& Hulings, 1976) and the observed intraspecific variation the identification is treated with a high degree of circumspection.

This species is consistently recorded from a wide depth range between $915 \mathrm{~m}$ and $3584 \mathrm{~m}$ in the material here, but is only common to superabundant at and below $1110 \mathrm{~m}$. Coles et al. (1990) record $H$. dasyderma from the Middle Miocene to Quaternary of the North Atlantic and Pacific oceans. Dingle et al. (1990) include specimens closely comparable to $H$. dasyderma within H. melobesiodes (Brady, 1869) in their Quaternary material offshore southwestern Africa (e.g. fig. 43A). Whatley et al. (1996) report $H$. dasyderma from $9 \mathrm{~m}$ to $c .500 \mathrm{~m}$ water depth in the southern Strait of Magellan, while Whatley et al. (1998) record $H$. dasyderma from deep waters between $1155 \mathrm{~m}$ and $2370 \mathrm{~m}$ in the Scotia Sea. A shallow occurrence, $64474 \mathrm{~m}$, is recorded off Marion Island (Dingle, 2002).

\section{Henryhowella sp. (Pl. 1, figs 8-10)}

In the material here this species was easily separated from Henryhowella cf. $H$. dasyderma (Brady) by virtue of its smaller size, densely spinose and prominent subcentral tubercle, distinct usually smooth hinge-ear in the left valve and, particularly in males, its long postero-ventral marginal spines. Although these features, together with the lack of longitudinal ridges or spine rows, also seem to separate it from previously described species, the authors prefer not to erect an additional new species because of the present taxonomic confusion surrounding the genus. This is largely the result of difficulty in recognizing consistent specific features in Henryhowella.

Henryhowella sp. is recorded between $215 \mathrm{~m}$ and $1408 \mathrm{~m}$ in the material here, although it is common only in the shallowerwater samples between $215 \mathrm{~m}$ and $280 \mathrm{~m}$. It seems to be replaced in deeper waters at and below $1110 \mathrm{~m}$ by $H$. cf. $H$. dasyderma (see above).

Explanation of Plate 5 .

figs 1-4. Krithe cf. K. praetexta (Sars), all from 54-5126, 425 m: 1, length 0.95 mm, adult left valve (USNM 483956) external lateral view; 2-4, length $0.92 \mathrm{~mm}$, adult carapace (USNM 483957); 2, right lateral view; 3, postero-dorsal oblique view; 4, dorsal view. figs 5-10. Krithe cf. K. capensis Dingle et al., all from 50-5120, $747 \mathrm{~m}$ : 5, length $0.95 \mathrm{~mm}$, male left valve (USNM 483959) external lateral view; 6, length $1.00 \mathrm{~mm}$, male right valve (USNM 483960) external lateral view; 7, length $0.82 \mathrm{~mm}$, female carapace (USNM 483958) dorsal view; 8, length $1.00 \mathrm{~mm}$, male right valve (USNM 483960) internal lateral view; 9, length $0.95 \mathrm{~mm}$, male left valve (USNM 483959) internal lateral view; 10, length $0.82 \mathrm{~mm}$, female carapace (USNM 483958) right lateral view. figs 11-16. Krithe dolichodeira van den Bold, all from Eltanin cruise 43, $787 \mathrm{~m}$ : 11, length $0.94 \mathrm{~mm}$, female right valve (USNM 483962) dorsal view; 12, length $1.10 \mathrm{~mm}$, female left valve (USNM 483961) external lateral view; 13, length $1.04 \mathrm{~mm}$, female right valve (USNM 483962) external lateral view; 14, length $1.10 \mathrm{~mm}$, male right valve (USNM 483963) external lateral view; 15, length $1.10 \mathrm{~mm}$ female left valve (USNM 483961) internal lateral view; 16, length $1.10 \mathrm{~mm}$, male right valve (USNM 483963) internal lateral view. figs 17-23. Krithe morkhoveni van den Bold, all from 48-5116, $1110 \mathrm{~m}$ : 17, length $1.20 \mathrm{~mm}$, male right valve (USNM 483966) external lateral view; 18, length $1.09 \mathrm{~mm}$, female left valve (USNM 483964) external lateral view; 19, length $1.10 \mathrm{~mm}$, female right valve (USNM 483965) external lateral view; 20, length $1.20 \mathrm{~mm}$, male right valve (USNM 483966) internal lateral view; 21, length $1.10 \mathrm{~mm}$, female right valve (USNM 483965) internal lateral view; 22, length 1.09 mm, female left valve (USNM 483964) external lateral view; 23, length $1.02 \mathrm{~mm}$, female right valve (USNM 483965) dorsal view. 
The form illustrated by Briggs (1978) as 'Echinocythereis' sp. from the Pleistocene Taylor Formation of Ross Island, Antarctica appears to be conspecific with the material here.

\section{Legitimocythere acanthoderma (Brady, 1880) (PI. 1, figs 6, 7)}

This species can be confused with Bathycythere audax but is easily separated, however, by virtue of its strongly spinose and well-developed subcentral tubercle present in all juvenile stages, its smaller size, denser spine distribution and reticulation which joins all spines. Legitimocythere Coles \& Whatley differs from Bathycythere Sissingh in muscle scar pattern: Legitimocythere has a 'V'-shaped frontal scar compared with the ovate frontal scar of Bathycythere. In addition, the subcentral tubercle is much more prominently developed in Legitimocythere compared with that of Bathycythere.

Legitimocythere acanthoderma is consistently present over a wide depth range between $425 \mathrm{~m}$ and $3584 \mathrm{~m}$ on the Kerguelen Plateau, although it is only common at and below $600 \mathrm{~m}$.

This is a common world-wide deep-sea species, originally described by Brady (1880) from $1375 \mathrm{fm}$. (2627 m) near Prince Edward Island (46 $\left.46^{\circ} \mathrm{S} ; 45^{\circ} 31^{\prime} \mathrm{E}\right)$. It has been recorded over a considerable depth range from as shallow as $318 \mathrm{~m}$ in Prydz Bay, Antarctica (Ayress, own data) to greater than $5000 \mathrm{~m}$ in the North Atlantic (Coles \& Whatley, 1989; Dingle \& Lord, 1990). In addition to the occurrences cited in Coles \& Whatley (1989), L. acanthoderma has also been recorded at $2916 \mathrm{~m}$ and $4736 \mathrm{~m}$ off southwestern Africa (Dingle et al., 1990), between $386 \mathrm{~m}$ and $456 \mathrm{~m}$ in the southern Strait of Magellan (Whatley et al., 1996) and at $2370 \mathrm{~m}$ in the Scotia Sea (Whatley et al., 1998).

\section{Legitimocythere presequenta (Benson, 1977) (PI. 1, figs 11-12, 14-16)}

The material here displays fine secondary reticulation, comprising a dense lace-like network on the valve surface, a feature not recorded previously in this species, and is considerably larger than the Eocene specimens illustrated by Coles \& Whatley (1989).

Legitimocythere presequenta is confined to the deepest analysed samples in the material here, between $2970 \mathrm{~m}$ and $3584 \mathrm{~m}$. This is a widely distributed abyssal species, although it is typically a rare component of any particular assemblage. Coles et al. (1990) record it from the Lower Eocene to Recent of the North Atlantic and the Pliocene to Quaternary of the Pacific; Ruan \& Hao (1988) record it from the Okinawa Trough and Ruan (1989) from the Xisha Trench, South China Sea. Coles \& Whatley (1989) detail other known occurrences. It is likely that this species has been previously under-reported, perhaps due to confusion with L. acanthoderma (Brady).

\section{Trachyleberis bathymarina Ayress, 1993 (Pl. 3, fig. 10)}

The type material from the Tasman Sea display fine secondary reticulation. The Kerguelen material lacks this ornament detail. Ayress (1993) has discussed the relationship of this species with other similar trachyleberid genera.

Trachyleberis bathymarina is superabundant at $915 \mathrm{~m}$ on the Kerguelen Plateau, and is also more rarely recorded in the material here between $1110 \mathrm{~m}$ and $2306 \mathrm{~m}$. Ayress (1993) described this species from the Late Quaternary to Recent of the
Tasman Sea between $1340 \mathrm{~m}$ and $2238 \mathrm{~m}$ water depth and from $1204 \mathrm{~m}$ to $3125 \mathrm{~m}$ water depth on the Chatham Rise.

\section{Polycope sp. (PI. 2, fig. 14)}

Ruan (1989) illustrates an identical form from around $2000 \mathrm{~m}$ in the South China Sea. In the Kerguelen material this species was found in two samples, commonly at $3584 \mathrm{~m}$, usually as juveniles.

\section{Manuscript received 14 December 2002 Manuscript accepted 17 November 2003}

\section{REFERENCES}

Abate, S., Barra, D., Aiello, G. \& Bonaduce, G. 1993. The genus Krithe Brady, Crosskey and Robertson, 1874 (Crustacea: Ostracoda) in the Pliocene-Early Pleistocene of the M. San Nicola Section (Gela, Sicily). Bollettino della Societa Paleontologica Italiana, 32: 349-366.

Ayress, M. 1993. On Trachyleberis bathymarina Ayress sp. nov. Stereo Atlas of Ostracod Shells, 20: 105-108.

Ayress, M. 1994. Cainozoic Palaeoceanographic and subsidence history of the eastern Margin of the Tasman Basin based on Ostracoda. In: Van der Lingen, G.J., Swanson, K.M. \& Muir, R.J. (Eds), The Evolution of the Tasman Sea Basin. Proceedings of the Tasman Sea Conference (November 1992, Christchurch, New Zealand). Balkema Publishers, Rotterdam, The Netherlands, 139-157.

Ayress, M. 1995. Late Eocene Ostracoda (Crustacea) from the Waihao District, South Canterbury, New Zealand. Journal of Paleontology, 69: 897-921.

Ayress, M. 1996. New Species and Biostratigraphy of Late Eocene Cytherurid Ostracoda from New Zealand. Revista Española de Micropaleontología, 18: 11-36.

Ayress, M. \& Drapala, V. 1996. New Recent and fossil discoveries of Cluthia (Leptocytheridae) in the Southwest Pacific: implications on its origin and dispersal. In: Keen, M. (Ed.), Proceedings of the $2^{\text {nd }}$ European ostracodologists meeting, University of Glasgow, Scotland, 23-27 July, 1993. British Micropalaeontological Society, London, $149-158$.

Ayress, M. \& Swanson, K. 1991. New fossil and recent genera and species of cytheracean ostracoda (Crustacea) from South Island, New Zealand. New Zealand Natural Sciences, 18: 1-18.

Ayress, M., Neil, H., Passlow, V. \& Swanson, K. 1997. Benthonic ostracods and deep watermasses: A qualitative comparison of Southwest Pacific, Southern and Atlantic Oceans. Palaeogeogeography, Palaeoclimatology, Palaeoecology, 131: 287-302.

Ayress, M., Barrows, T., Passlow, V. \& Whatley, R. 1999. Neogene to Recent species of Krithe (Crustacea: Ostracoda) from the Tasman Sea and off Southern Australia with decription of five new species. Records of the Australian Musuem, 51: 1-22.

Belkin, I.M. \& Gordon, A.L. 1996. Southern Ocean fronts from the Greenwich meridian to Tasmania. Journal of Geophysical Research, 101: 3675-3696.

Benson, R. 1964. Recent Cytheracean ostracodes from McMurdo Sound and the Ross Sea, Antarctica. University of Kansas Paleontological Contribributions, Arthropoda, 6: 1-36.

Benson, R., Delgrosso, R. \& Steineck, P. 1983. Ostracode distribution and biofacies, Newfoundland continental slope and rise. Micropaleontology, 29: 430-453.

Brady, G.S. 1880. Report on the Ostracoda dredged by H.M.S. Challenger during the years 1873-1876. Reports of the Scientific Voyage of H.M.S. Challenger; Zoology, 1: 1-184.

Brady, G.S. \& Norman, A. 1889. A monograph of the marine and freshwater Ostracoda of the North Atlantic and of northwestern Europe. Section I: Podocopa. Scientific Transactions of the Royal Dublin Society, 4: 63-270.

Briggs, W.M. 1978. Ostracoda from the Pleistocene Taylor Formation, Ross Sea, and the Recent of the Ross Sea and McMurdo Sound region, Antarctica. Antarctic Journal of the United States, 13: 27-29.

Chapman, F. 1919. Ostracoda from soundings obtained during the cruises of the S.Y. Aurora. Scientific Reports of the Australasian Antarctic Expedition, ser. C, 5: 1-48. 
Coffin, M.F., Frey, F.A., Wallace, P.J. \& shipboard party 2000. ODP leg 183 - Kerguelen Plateau-Broken Ridge: A large Igneous Province. Proceedings of the Ocean Drilling Program, 183: 101pp.

Coles, G. \& Whatley, R. 1989. New Palaeocene to Miocene genera and species of Ostracoda from DSDP sites in the North Atlantic. Revista Española de Micropaleontología, 22: 81-124.

Coles, G., Ayress, M. \& Whatley, R. 1990. A comparison of Cainozoic deep-sea Ostracoda from the $\mathrm{N}$ Atlantic and Pacific oceans. In: Whatley, R.C. \& Maybury, C. (Eds), Ostracoda and global events. Proceedings of the 10th International Symposium on Ostracoda, Aberystwyth, Wales. Chapman and Hall, London, 287-305.

Coles, G., Whatley, R. \& Moguilevsky, A. 1994. The ostracod genus Krithe from the Tertiary and Quaternary of the North Atlantic. Palaeontology, 37: 71-120.

Corrège, T. 1993. The relationship between water masses and benthic ostracod assemblages in the western Coral Sea, Southwest Pacific Palaeogeography, Palaeoclimatology, Palaeoecology, 105: 245-266.

Cronin, T. 1996. Deep water North Atlantic ostracods and Pliocene palaeoceanography (3.2-2.8 Ma), DSDP Sites 610A and 607. In. Moguilevsky, A. \& Whatley, R. (Eds), Microfossils and Oceanic Environments. University of Wales, Aberystwyth-Press, 39-46.

Cronin, T., Holtz, T.R. Jr \& Whatley, R.C. 1994. Quaternary Paleoceanography of the deep Arctic Ocean based on quantitative analysis of Ostracoda. Marine Geology, 119: 305-332.

Cronin, T., Holtz, T.R. Jr, Stein, R., Spielhagen, R., Fütterer, D. \& Wollenburg, J. 1995. Late Quaternary Paleoceanography of the Eurasian Basin, Arctic Ocean. Paleoceanography, 10: 259-281.

Dingle, R. 1994. Quaternary ostracods from the continental margin off south-western Africa. Part III. Oceanographical and sedimentary environments. Annals of the South African Musuem, 103: 383-441.

Dingle, R. 2002. Insular endemism in Recent Southern Ocean benthic Ostracoda from Marion Island: palaeozoogeographical and evolutionary implications. Revista Española de Micropaleontología, 34: $215-233$

Dingle, R. 2003. Some palaeontological implications of putative, longterm, gene reactivation. Journal of the Geological Society, London, 160: $815-818$.

Dingle, R. \& Giraudeau, J. 1993. Benthic Ostracoda in the Benguela System (SE Atlantic): a multivariate analysis. Marine Micropaleontology, 22: 71-92.

Dingle, R. \& Lord, A. 1990. Benthic ostracods and deep watermasses in the Atlantic Ocean. Palaeogeography, Palaeoclimatology, Palaeoecology, 80: 213-235.

Dingle, R., Lord, A. \& Boomer, I. 1989. Ostracod faunas and water masses across the continental margin off Southwestern Africa. Marine Geology, 87: 323-328.

Dingle, R., Lord, A. \& Boomer, I. 1990. Deep-water Quaternary Ostracoda from the continental margin off south-western Africa (SE Atlantic Ocean). Annals of the South African Musuem, 99: 245-366.

Guernet, C. \& Moullade, M. 1994. Late Miocene-Early Pliocene Ostracods in Deep Oceanic Environment (Central Atlantic). Revue de Micropaléontologie, 37: 257-274.

Kaesler, R.L., Kontrovitz, M. \& Taunton, S. 1993. Crushing strength of Puriana pacifica (Ostracoda). An experimental approach to taphonomy. Journal of Paleontology, 67: 1005-1010.

Majoran, S. \& Dingle, R. 2002. Cenozoic deep-sea ostracods from Maud Rise, Weddell Sea, Antarctica (ODP Site 689): a palaeoceanographic perspective. Geobios, 35: 137-152.

Müller, G.W. 1908. Die Ostracoden der Deutschen Südpolar-Expedition 1901-1903. In: von Drygalski, E. (Ed.), Deusche Südpolar-Expedition 10. Zoologie, 2. Verlag von Georg Reimer, Berlin, 51-181.

Müller, A. \& De Deckker, P. 2003. Magnesium, calcium and strontium in waters of the southern Tasman Sea at the confluence of the Indian, Pacific and Southern Oceans. Marine and Freshwater Research, 53 $1115-1128$

Neale, J. 1967. An ostracod fauna from Halley Bay, Coats Land, British Antarctic Territory. British Antarctic Survey Scientific Reports, 58: $50 \mathrm{pp}$.

Neil, J.V. 2002. Variation in surface morphology of a Miocene hemicytherid ostracode. Alcheringa, 26: 289-297.

Nohara, T. 1987. Cenozoic Ostracodes of Okinawa-Jima. Bulletin of College of Education, University of the Ryukyus, 30: 105pp.
Orsi, A.H., Whitworth, T. \& Nowlin, W.D. 1995. On the meridional extent and fronts of the Antarctic Circumpolar Current. Deep-Sea Research, 40: 169-203.

Passlow, V. 1994. Late Quaternary history of the Southern Ocean offshore southeastern Australia, based on Ostracoda. PhD thesis. Australian National University, Canberra, 265pp.

Passlow, V. 1997. Slope sedimentation and shelf to basin sediment transfer: a cool-water carbonate example from the Otway margin, southeastern Australia. SEPM Special Publication, 56: 107-125.

Passlow, V. \& Ayress, M. 1994. On Cytheropteron abyssorum Brady. Stereo Atlas of Ostracod Shells, 21: 63-70.

Puri, H. \& Hulings, N. 1976. Designation of lectotypes of some ostracods from the Challenger expeditions. Bulletin of the British Museum (Natural History), Zoology, 29: 254-314.

Ruan, P. 1989. Systematic description of genera and species. IV. Ostracoda. In: Wang, P. (Ed.), Quaternary microbiotas and their geological significance from Northern Xisha Trench of the South China Sea. Geological Publishing House, Beijing, 116-132.

Ruan, P. \& Hao, Y. 1988. Systematic description of microfossils, 2. Ostracoda. In: Rong, L. \& Shu, Z. (Eds), Quaternary microbiotas in the Okinawa Trough and their geological significance. Geological Publishing House, Beijing, 227-395.

Schornikov, E. 1976. Adaptation pathways of Ostracoda to Seistonophagy. In: Hartman, G. (Ed.), Evolution of post-Paleozoic Ostracoda. Proceedings of the 5th International Symposium on Ostracoda, Hamburg, Germany. Verlag Paul Parey, Hamburg, 247-257.

Schornikov, E. 1981. Ostracodes Bythocytheridae of the Fareastern Seas. Akademy Nauka, Moscow (In Russian), 200pp.

Sissingh, W. 1974. On Bathycythere vanstraateni Sissingh, 1971. Stereo Atlas of Ostracod Shells, 2: 133-140.

Swanson, K. 1995. Strategies for, and evolutionary implications of, carapace conservation in some living, benthic, marine Ostracoda. Senckenbergiana lethaea, 75: 193-213.

Swanson, K. \& Ayress, M. 1999. Cytheropteron testudo and related species from the SW Pacific with analyses of their soft anatomies, relationships and distribution. Senckenbergiana Biologica, 79: 151-193.

Tomczak, M. \& Godfrey, J.S. 1994. Regional Oceanography: An Introduction. Pergamon Press, London, 422pp.

Van Morkhoven, F.P.C.M., Berggren, W.A. \& Edwards, A.S. 1986. Cenozoic cosmopolitan deep-water benthic foraminifera. Bulletin Centres Recherches Exploration- Production, Elf-Aquitaine, Memoir, 11: $421 \mathrm{pp}$.

Whatley, R. 1985. Evolution of the ostracods Bradleya and Poseidonamicus in the deep-sea Cainozoic of the South-West Pacific. Special papers in Palaeontology, 33: 103-116.

Whatley, R. \& Ayress, M. 1988. Pandemic and endemic distribution patterns in Quaternary deep-sea Ostracoda. In: Hanai, T., Ikeya, N. \& Ishizaki, K. (Eds), Evolutionary biology of Ostracoda - its fundamentals and applications. Proceedings of the 9th International Symposium on Ostracoda, Shizuoka, Japan. Elsevier, Tokyo, 739-755.

Whatley, R. \& Coles, G. 1987. The late Miocene to Quaternary Ostracoda of Leg 94, Deep Sea Drilling Project. Revista Española de Micropalaeontología, 14: 33-97.

Whatley, R. \& Coles, G. 1991. Global change and the biostratigraphy of North Atlantic Cainozoic deep water ostracoda. Journal of Micropaleontology, 9: 119-132.

Whatley, R., Downing, S., Kesler, K. \& Harlow, C. 1986. The ostracod genus Poseidonamicus from the Cainozoic of D.S.D.P. sites in the S. W. Pacific. Revista Española de Micropaleontologia, 18: 387-400.

Whatley, R., Chadwick, J., Coxhill, D. \& Toy, N. 1988. The ostracod family Cytheruridae from the Antarctic and south-west Atlantic. Revista Española de Micropaleontología, 20: 171-203.

Whatley, R., Millson, K. \& Ayress, M. 1992. Philoneptunus, a new ostracod genus from the Cainozoic of Australasia. Revista Española de Micropaleontología, 24: 43-62.

Whatley, R., Staunton, M., Kaesler, R.L. \& Moguilevsky, A. 1996. The taxonomy of Recent Ostracoda from the southern part of the Strait of Magellan. Revista Española de Micropaleontología, 28: 51-76.

Whatley, R., Staunton, M. \& Kaesler, R.L. 1997. The depth distribution of recent marine Ostracoda from the southern Strait of Magellan. 
M. A. Ayress et al.

Journal of Micropalaeontology, 16: 121-130.

Whatley, R., Moguilevsky, A., Ramos, M. \& Coxhill, D. 1998. Recent deep and shallow water ostracoda from the Antarctic Peninsula and the Scotia Sea. Revista Española de Micropaleontología, 30: $111-135$.

World Ocean Atlas. 1994. CD-Roms vols 1, 2 and 3. Supplied by NOAA, United States Department of Commerce, Washington, USA.
Zhou, B. \& Ikeya, N. 1992. Three species of Krithe (Crustacea: Ostracoda) from Suruga Bay, Central Japan. Transactions of the proceedings of the Palaeontological Society of Japan, 166: 1097-1115. Zhou, Q. \& Whatley, R. 1997. Distribution of the ostracod genera Krithe and Parakrithe in bottom sediments of the East China and Yellow seas. Marine Micropaleontology, 32: 195-207. 